Potravinarstvo Slovak Journal of Food Sciences

vol. 15, 2021, p. 396-422

https://doi.org/10.5219/1592

Received: 29 March 2021. Accepted: 29 April 2021.

Available online: 28 May 2021 at www.potravinarstvo.com

(C) 2021 Potravinarstvo Slovak Journal of Food Sciences, License: CC BY 4.0

ISSN 1337-0960 (online)

\title{
HYGIENE MEASURES IN SUPERMARKETS, RETAIL FOOD STORES, AND GROCERY SHOPS DURING THE COVID-19 PANDEMIC IN SLOVAKIA
}

\author{
Peter Zajác, Jozef Čurlej, Lucia Benešová, Jozef Čapla
}

\begin{abstract}
The article presents the hygiene measures that are applied in the Slovak Republic in supermarkets, food stores, grocery stores as a result of the COVID-19 pandemic situation in Slovakia. These measures have been published by the Public Health Authority of the Slovak Republic in the relevant legal regulations and are based on the decisions of the Government of the Slovak Republic, which took into account the opinions of the experts of the Pandemic Commission of the Government of the Slovak Republic. In general, these measures are based on the mask-distance-hand principle. In public areas outside and inside, it was ordered to wear masks and later wear a respirator of FFP2 class in exterior and interior, gloves on hands or disinfection of customers' hands before entering the store, observance of $2 \mathrm{~m}$ distance of people standing in a row at the cash registers, maximum capacity of persons in stores was determined one person per $25 \mathrm{~m}^{2}$ of sales area and later, this measure was tightened to $15 \mathrm{~m}^{2}$ of sales area. Also, to perform regular ventilation of the premises and to have as many cash registers as possible so as not to create long lines of customers. All shops were closed at 8:00 PM. In the case of shopping centers, entry is prohibited for people with a body temperature higher than $37{ }^{\circ} \mathrm{C}$, and disinfection of hands is mandatory, wearing a mask and later wear respirators of FFP2 class is necessary. In a stricter regime, during the peak of the pandemic, there was a restriction for persons to shop food only in the nearest retail/grocery or similar place from the place of residence to the extent necessary to procure the essential needs of life.
\end{abstract}

Keywords: hygiene measure; COVID-19; Slovakia; food supermarket; food store; grocery store; grocery shop; grocery

\section{INTRODUCTION}

Every food business operator in European Union is required to follow the legal requirements for food safety. Supermarkets, grocery stores, and other businesses in the food retail sector are no exception in Slovakia. These legal requirements are given by EU General Food Law (EU, 2002), EU Food Hygiene Low (EU, 2004) and the Slovak Food Law (NR SR, 1995) including several decrees based on this law, in which the sale of meat and meat products (MPRV SR, 2012a), bakery products (MPRV SR, 2014), perishable food (MPRV SR, 2012b) is described. The general principles of food safety require every business operator along the food chain to ensure that the safety of food is proactively managed and maintained.

During the COVID-19 pandemic, other relevant legal requirements were adopted by the Government of the Slovak Republic, Ministry of Health of the Slovak Republic, and The Public Health Authority of the Slovak Republic (PHA SR).

The PHA SR is a budgetary organization of the state with competence on the territory of the Slovak Republic with the registered office in Bratislava, linked with the financial relations to the budget of the Ministry of Health. The PHA
SR is managed and its activity falls under the responsibility of the Chief Hygienist of the Slovak Republic Ján Mikas, $\mathrm{PhDr}$., RNDr., MD, PhD. who is also the director of the office. The chief hygienist is appointed and dismissed upon the proposal of the Minister of Health of the Slovak Republic by the director of the office of the ministry. The Public Health Authority of the Slovak Republic is the supreme office for the regional public health authorities. It manages, controls, and coordinates the execution of state administration carried out by regional public health offices. More details on competencies and activities of the Authority in the field of protection, promotion, and development of public health are stated in the Act number 355/2007 Collection of Laws of the Slovak Republic (Act on the Protection, Promotion, and Development of Public Health and on Amendments to Certain Acts).

The development of the pandemic situation in Slovakia is presented in Figure 1 (Confirmed cases) and Figure 2 (Deaths). The Government of the Slovak Republic has set up a specialized website www.korona.gov.sk, where the public can find out basic information about the pandemic situation, including preventive hygiene measures, restrictions, and exceptions. 


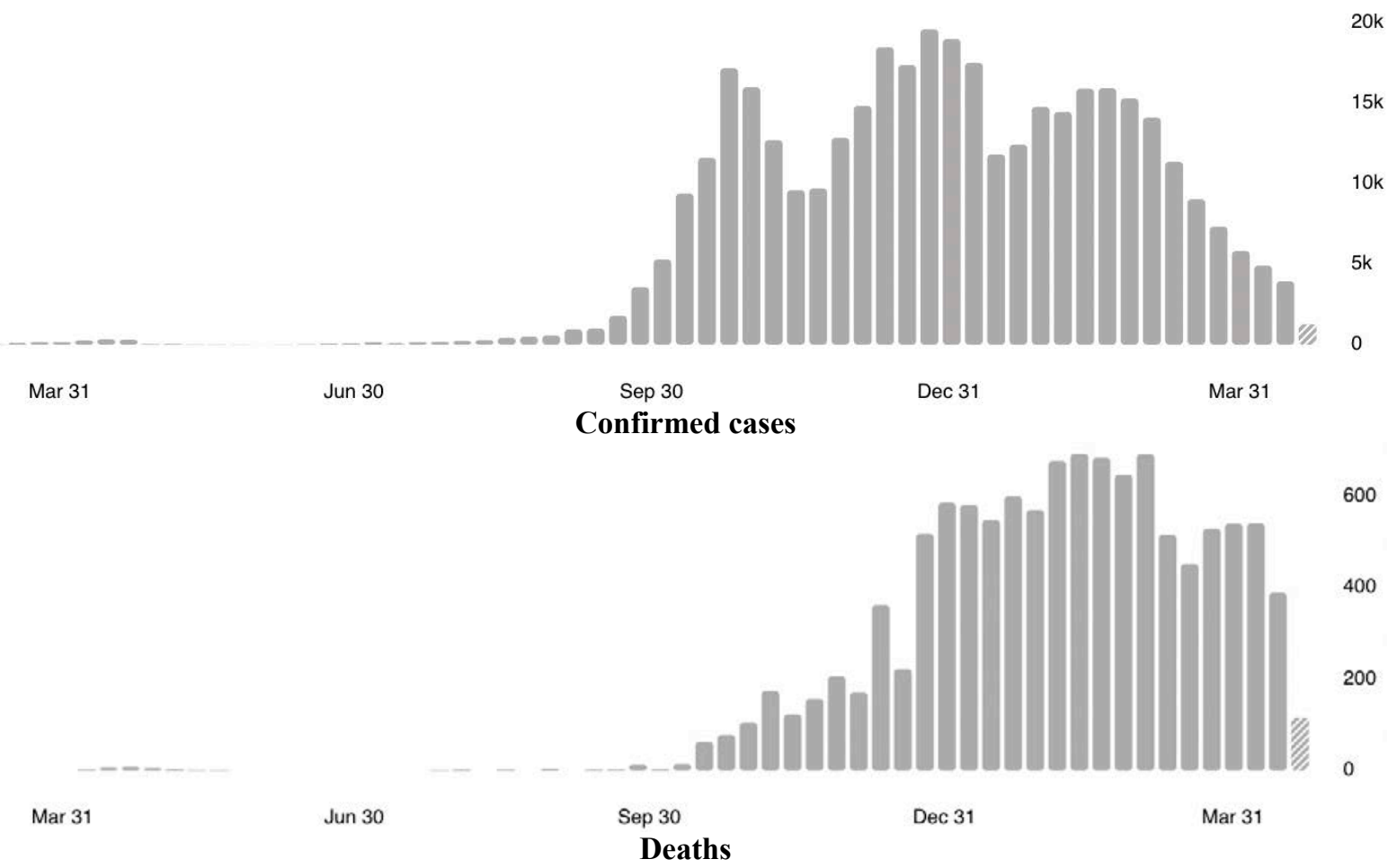

Figure 1 Development of the epidemic situation in Slovakia 6.3. 2020. - 26.4.2021 (WHO, 2021).

Note: In Slovakia, from 3 January 2020 to 5:14pm CEST, 28 April 2021, there have been 381,180 confirmed cases of COVID-19 with 11,611 deaths, reported to WHO. As of 18 April 2021, a total of 1,310,241 vaccine doses have been administered.

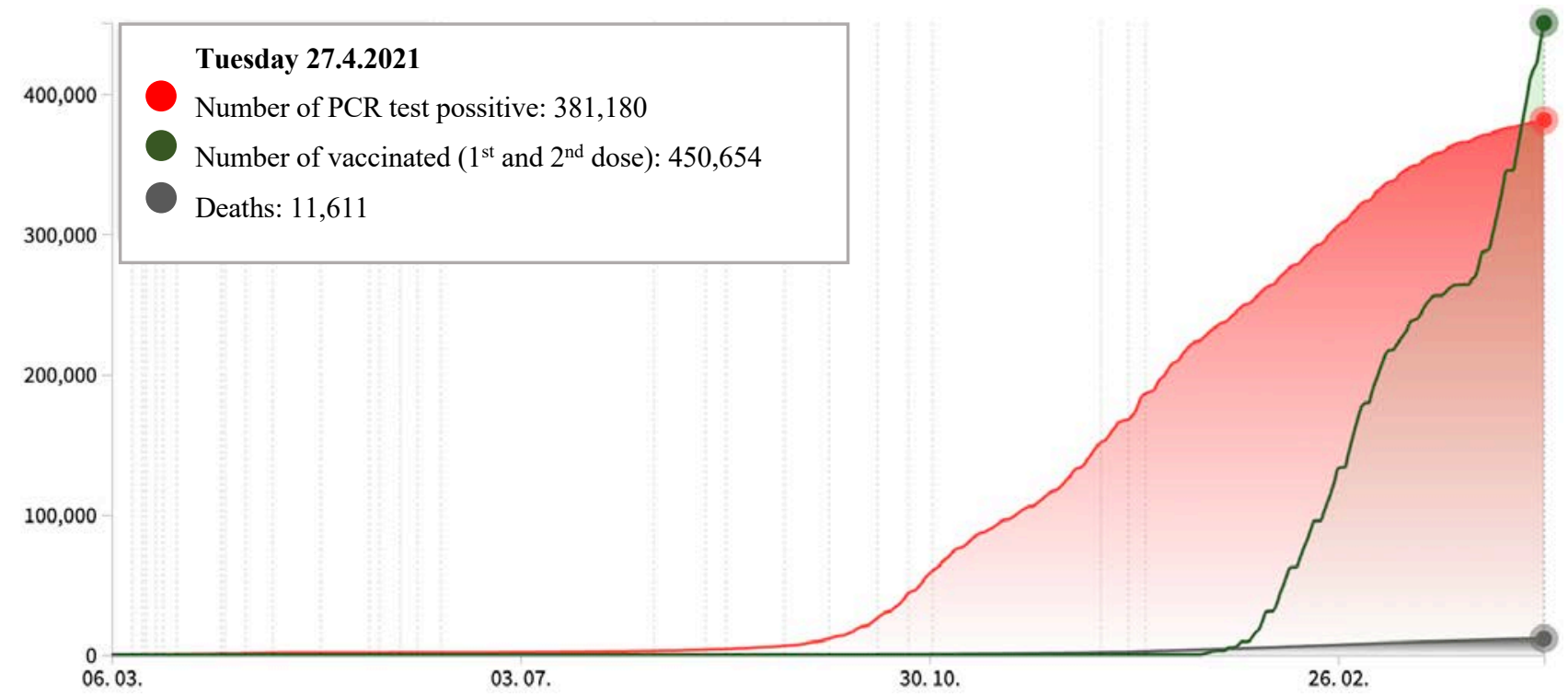

Figure 2 Development of the epidemic situation in Slovakia 6.3.2020. - 27.4.2021 (MIRDI SR, 2021a).

\section{Covid Automat}

Covid Automat is the monitoring and signaling system of the Ministry of Health of the Slovak Republic. This system is providing early warning of uncontrolled spread of the disease so that the health system can take action the necessary preventive measures and the uncontrolled spread of the disease in advance, as well as during the ongoing critical situation, to contribute to its stabilization and gradual improvement. It enables the predictable set of measures - balancing economic activity and public health. This system aims to provide measures that are: simple, comprehensible, predictable, targeted, enforceable, secure, and consistent with the legislation. For more efficient and sustainable management of the pandemic, it is necessary to worsening of the epidemiological situation and preventing its deterioration by monitoring the cohort epidemiological criteria, the key ones being:

- number of cases (average number of cases in 7 days) $=$ future workload,

- increase in the number of hospitalizations $=$ current burden,

- $\mathrm{Rt}=$ dynamics.

The basis for quality and effective measures in pandemic management is compliance with 4 basic criteria that need to be taken into account when recruiting departmental traffic lights: Security, Insulation, Surveillance, and Protection (MH SR, 2021). The covid automat shoving the epidemiological situation on the map (Figure 3). 


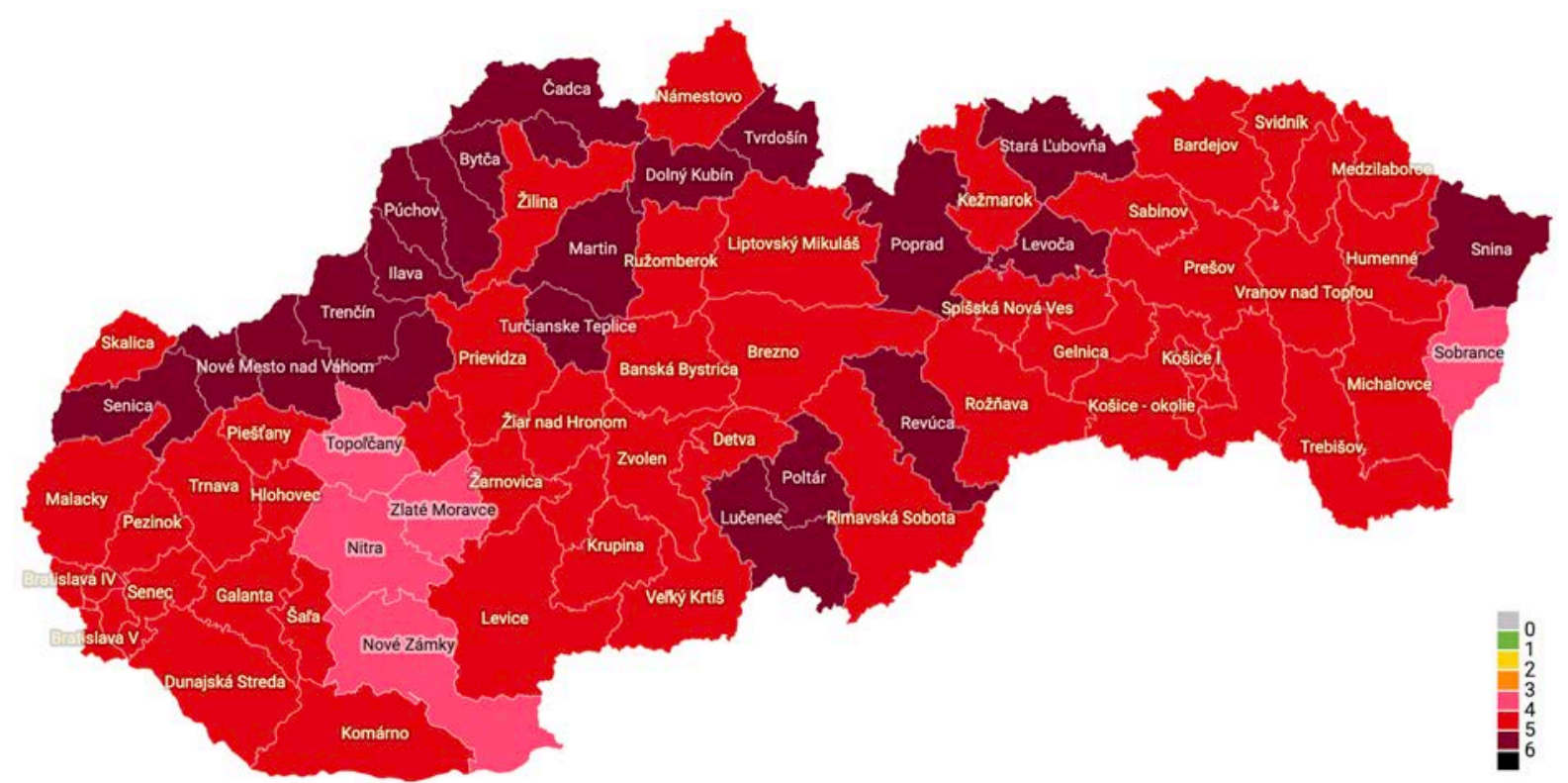

Figure 3 Actual regional Covid Automat 26.4.2021 - 2.5.2021 (MIRDI SR, 2021b).

UNI Global Union has developed guidelines to protect food retailers from COVID-19 exposure. The recommendations were developed following a collection of best practices from UNI's affiliated trade unions around the world. They are designed to be implemented for all supermarket staff, despite different conditions in different regions. UNI encourages its sales offices to use guidelines when dealing with employers to ensure the protection and rights they deserve from food retailers. Christy Hoffman, UNI Secretary-General, said: "I was concerned and deeply saddened to see a growing number of grocery store workers who were infected with COVID-19 while bravely serving the public, despite the risk to their health and the health of their families." Too many have already died. It doesn't have to be that way. Supermarket workers and customers must be provided with the highest level of protection - as described in these guidelines." "These measures will not only ensure better safety for workers but will also help ensure the safety of supermarkets for all in the face of COVID-19," says Mathias Bolton, UNI store manager. "Healthy workers and safe shops are essential because supermarkets are the most visited places during this pandemic." Without proper safety and protection in shops, the risk of infection increases. That is why we say: protect workers, protect the public." UNI has launched a declaration obliging employers to work with uni and its affiliated departments to share and implement the highest hygiene and safety standards in stores across their operations. It has already been signed by the multinational retailer Carrefour, Auchan, and El Corte Inglés (UNI Global Union, 2020).

Despite COVID-19 is a respiratory illness with a mode of invasion through the respiratory tract, not the gastrointestinal tract, an average food consumer is anxious and concerned about food safety (Pressman, Satyanarayan and Roger, 2020).

Governments must take appropriate measures to prevent the spread of the disease. Examples of measures taken by governments include such as enforcing the proper lockdown among the people; ensure food security by providing the citizens with basic necessities or letting them buy food in the store from the retailers; enforcing and monitoring law and order during the whole pandemic and especially during lockdown period in public places, public transportation, markets, shop, and medical facilities; and identification and treatment of people suffering from coronavirus attack (Hassen, El Bilali and Allahyari, 2020; Jain, Puri and Jain, 2021).

In addition to these measures, the government and the competent authorities should provide an information campaign for the population where consistently, simply, briefly explain to the population what is allowed and what is forbidden, what measures they must follow. Moreover, measures adopted by the competent authorities are then communicated by food retailers to customers at their premises. Individual retailers choose different ways of informing consumers. They should use various pictograms, posters, flyers, stickers, information banners, tv banners, websites, etc. to inform buyers.

The Public Health Authority of the Slovak Republic issued hygiene measures in the form of decrees and published them in the collection of laws of the Slovak Republic. The Government of the Slovak Republic and the Public Health Authority of the Slovak Republic regularly informed citizens and media at press conferences and in the national media Slovak Radio and Television. A special campaign was created, which was broadcast by the media at the time of the commercial broadcast between television programs and radio programs. Basic pictograms were published by the PHA SR to show the principle of Mask - Distance Hands (Figure 4, a). On the other hand, the legislation did not make these pictograms mandatory. Supermarkets, retail food stores, and grocery shops start to improvise and invent information materials, pictograms especially in their corporate colors, and communicated them to the public (Figure 4, b, c, d). Size, contrast, resolution, limitations of people with color or visual impairments were unlikely to be taken into account. The blue color mostly indicating the recommendation and the red color signaling the restriction were not used consistently. Also, various corporate colors were used, yellow (Figure 7) green (Figure 12). 


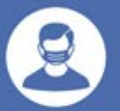

Rúško

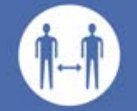

Odstup

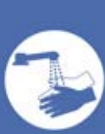

Ruky a) Note: Mask, distance, hands.

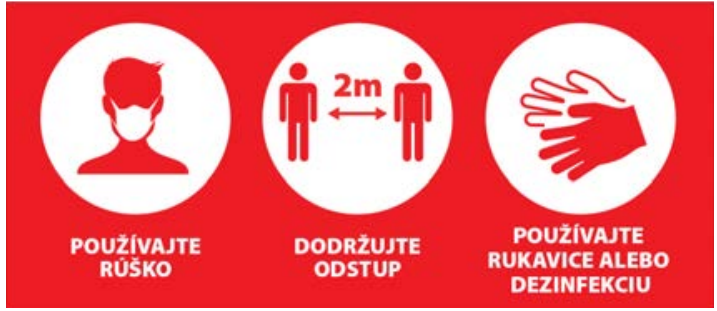

b) Note: Wear a mask, keep a distance, wear gloves or disinfectant.

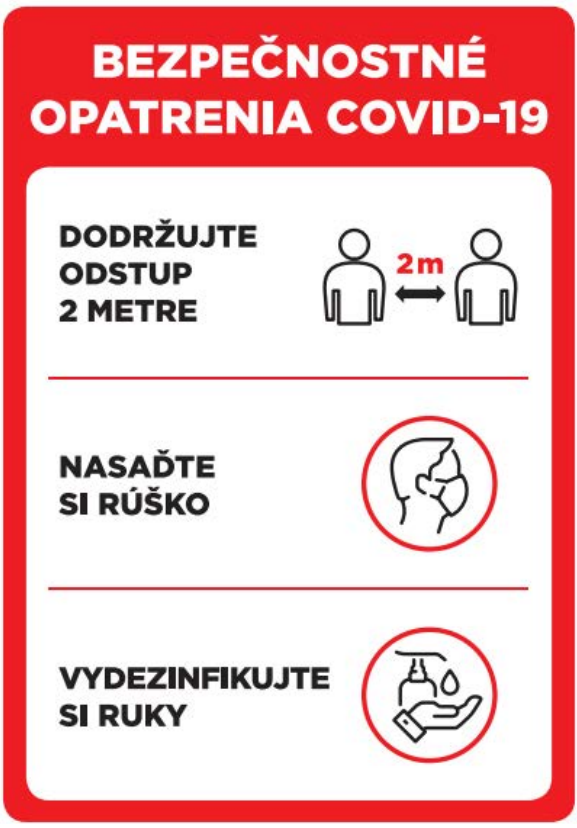

c) Note: Safety measures COVID-19.

Keep a distance of $2 \mathrm{~m}$, put on your mask, disinfect your hands.

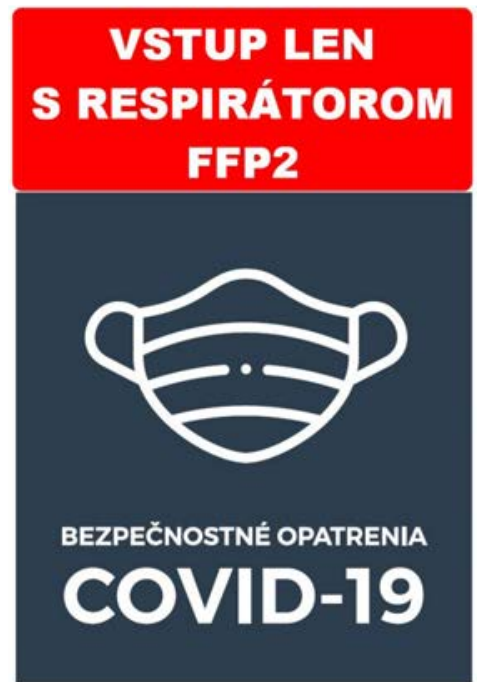

d) Note: Entry only with FFP2 respirator. Precautions COVID- 19.

Figure 4 Example of pictograms with information on measures to ensure protection against COVID-19 disease.

\section{Scientific Hypothesis}

Customers perceive anti-epidemiological measures applied in food stores as sufficient.

\section{MATERIAL AND METHODOLOGY \\ Samples}

Our sample consisted of respondents from all over Slovakia. The structure of the respondents was:

- Total number of respondents: 1,000

- Man: $28 \%$

- Woman: $72 \%$

The age categories:

$$
\begin{array}{ll}
- & 18-30: 31 \% \\
- & 31-40: 26 \% \\
- & 41-50: 18 \% \\
- & 51-64: 15 \% \\
- & 65 \text { and }>: 10 \%
\end{array}
$$

Education:

$$
\begin{array}{ll}
\text { - } & \text { Basic (primary-school): } 0 \% \\
\text { - } & \text { Secondary (high-school): } 42 \% \\
\text { - } & \text { Higher education (university): } 58 \%
\end{array}
$$

\section{Description of the Experiment}

Questionnaire preparation: In creating the questionnaire, we relied on hygiene measures proposed by the Public Health Authority of the Slovak Republic and. We formulated some questions in such a way as to find out the overall perception of hygiene measures by the respondents. Respondents were allowed to answer the questions yes or no. There was a possibility to write the opinion regarding the questions. All questions were mandatory.

Number of questions analyzed: 14

1. Do you think that COVID measures in stores are sufficient? (Yes/No)

2. Was there a notice regarding the hygiene measures for customers in connection with COVID-19 before entering the store (picture, text)? (Yes/No)

3. Was there a disinfectant for customers before entering the store? (Yes/No)

4. Does the seller disinfect baskets and carts? (Yes/No)

5. Do customers have disposable gloves available for handling unpackaged products? (Yes/No)

6. Do you think that the frequency of disinfection of areas with which customers come into direct contact is sufficient (handles and handles on refrigerators/freezers, pastry tongs, belts on cash registers, etc.)? (Yes/No)

7. Was the overall cleanliness in the store satisfactory?

8. Is the observance of distances between customers in the store premises checked in the store? (Yes/No)

9. Is the observance of the spacing in the rows at the cash registers checked? (Yes/No)

10. Have you encountered a situation where a person of a younger age category was present in the store during the time set aside for the purchase of seniors from 9:00 to 11:00? (Yes/No)

11. Did you witness that the staff or customer did not have an FFP2 respirator in the store? (Yes/No)

12. Did you witness that the staff or customer did not have a properly fitted respirator in the store? (Yes/No)

13. Do you use the service of buying goods by delivery directly to your home? (Yes/No)

14. Do you only pay for your purchase with a payment card? (Yes/No) 
Conducting a questionnaire survey: the online questionnaire survey was conducted via the social media Facebook and Instagram. The questionnaire was prepared by Google Form, firstly validated by our research team, and consequently shared with people on social media. Only one person from the research team had access to the collected raw data. We prevented any manipulation of these data. We complied with the requirements of the GDPR legislation of the European Union. Data collection was anonymous. Each participant could complete the questionnaire only once. The survey took place in the period: $15^{\text {th }}$ of April $2021-25^{\text {th }}$ April 2021.

\section{Number of answers:}

The total number of processed answers was 14,0000 .

\section{Creating a dataset:}

We processed the raw data. Each verbal answer was examined. Offensive and vulgar responses were deleted. We performed a grammatical correction of text answers. and prepared the final data set for further processing in Microsoft Excell (Office 365). The structure of the dataset was adapted to further statistical processing.

Processing the answers:

We evaluated all questions and visualized the consumers' opinions by figures.

We evaluated the individual text answers and formulated the most frequent opinions of consumers. These answers are presented in the discussion section of this article.

\section{Statistical Analysis}

Multiple correspondence analysis was used to visualize the data obtained from the questionnaire survey. Statistical significance was determined based on the significance of the $p$-value. The statistical program $\mathrm{R}$ studio (vs. 1.3.959) was used for data processing. Multiple correspondence analysis (MCA) is an extension of simple correspondence analysis to summarize and visualize a data table containing more than two categorical variables. It can also be understood as a generalization of the analysis of the main components when the variables to be analyzed are qualitative instead of quantitative (Abdi and Williams, 2010).

\section{RESULTS AND DISCUSSION}

A COVID-19 pandemic is an unprecedented event in the past 100 years of human history. It has started at the end of the year 2019 when a novel coronavirus SARS-CoV-2 (named by the International Committee on Taxonomy of Viruses) was discovered in Wuhan, China (Huang et al., 2020; Chan et al., 2020; Wu et al., 2020). The disease spreads rapidly to all provinces of China outside of Wuhan (Li et al., 2020; Tan et al., 2020), since then COVID-19 has been spreading exponentially around the globe. Based on available data, the Centers for Disease Control and Prevention (CDC, 2020a) stated that COVID-19 appears to be disseminating primarily from individual to individual, resulting in respiratory disease, and deaths of elderly adults and individuals at any age who have severe medical problems (Jribi et al., 2020). Dangerous for critically ill COVID-19 patients with pneumonia are symptoms on a large scale with no specific drug treatment. Severe inflammatory reaction and respiratory distress syndrome can lead to rapid progression of the disease and may cause death (Wang et al. 2020a). An excessive release of inflammatory immune cytokines could increase inflammation of the lung and risk occurrence of acute respiratory distress syndrome (ARDS) (Huppert, Matthay and Ware et al., 2019), this may lead to hypoxia and lung injury, causing a further release of inflammatory factors (Butt, Kurdowska and Allen, 2016; Mokra and Kosutova, 2015; Paolone, 2017). The large area of infection and the inflammatory reaction causes many immunologic problems, such as cytokine release syndrome (CRS), which can rapidly lead to deterioration and death (Zhao et al., 2019; Tanaka, Narazaki and Kishimoto, 2016). The Virus's health impact as well as the sharp effect on economic and business activities, mostly due to the lack of effective vaccines or treatments are well known today. Several countries, have preferred a shutdown approach to slow down the transmission of the novel virus, by reducing the number of social contacts, and stopping all unessential economic and business activities including shutting schools and universities, Ferguson et al., 2020 proposed that lockdowns will need to be carried out on a fairly regular basis for more than a year. In many countries, government declarations of lockdown have led to a panic buying of food-like products (Jribi et al., 2020), this kind of behavior is clearly described by the study of Wang et al. (2020a) who stated psychological effects, fear, anxiety, and stress caused by the pandemic. A partly positive report has been presented by the Centers for Disease Control and Prevention who stated that there is no proof that the novel coronavirus can be transmitted by interaction with food or food packaging (CDC, 2020b). Besides this, it is always important to practice strict hygiene when handling food (UNICEF, 2020). To reduce the transmission of the virus among the population, legislation has been adopted in Slovakia that also addresses the sale of food. An overview of specific measures in chronological order is given in the next chapter.

The overview of the general COVID-19 pandemic measures in Slovakia

Slovakia was among the first countries in the world (and the second in Europe, after the Czech Republic) to make the wearing of masks mandatory in public (URL 1, 2020).

The population of the Slovak Republic strictly adhered to the measures at the beginning of the pandemic when little information was available about the disease and people was scared. The government adopted the first measures in March 2020. The chronology of the most important measures was: $8 / 3 / 2020$ secondary schools closed in Bratislava region; 9/3/2020 primary schools closed; 10/3/2020 events suspended; 12/3/2020 all event venues closed; 13/3/2020 compulsory 14-day quarantine upon returning from abroad; 15/3/2020 face masks compulsory in public transport and shops; 16/3/2020 non-essential stores closed; 25/3/2020 compulsory face masks in public; $6 / 4 / 2020$ compulsory 14-day quarantine upon returning from abroad in a quarantine accommodation facility; 8-14/4/2020 curfew during the Easter seasion; 22/4/2020 allowed activities, shops under $300 \mathrm{~m}^{2}$, long-term accommodation, outdoor non-contact sports, car selling, open-air markets; 6/5/2020 short-term accommodation without restaurants or eating in common areas, pedicures and manicures, outdoor tourism, taxi services, services and 
weddings, massages, museums, galleries, libraries, exhibition halls; 20/5/2020 Concentration of people inside of stores increased from 1 person $/ 25 \mathrm{~m}^{2}$ to 1 person / $15 \mathrm{~m}^{2}$. Theatres and cinemas opened, events with less than 100 participants allowed. Shopping malls reopened. Swimming pools and gyms open for members of sports clubs. Restaurant interiors are now accessible. Face masks no longer mandatory when the distance between people is at least 5 meters. Schools and Kindergartens to be opened later on 1 June 2020. Residents of Slovakia can now pass the borders and not go into state quarantine as long as they return in under 24 hours; 1/10/2020 Face masks are again compulsory even in exterior spaces if separation of at least 2 meters between persons cannot be maintained. Mass events were restricted to less than 50 people. Restaurants and bars must close by 10 PM and shopping malls must maintain at least 10 meters squared and 2 meters separation per customer. Universities must switch to distanced learning; 15/10/2020 Mass events were banned, except for baptisms, funerals, and weddings, which must maintain at least 15 meters squared per person. Shops and shopping malls must also maintain at least 15 meters squared per customer and must check the customer's body temperature. 9 to 11 AM is reserved for senior citizens. Sports events must be without spectators. Restaurants must serve customers only in exterior spaces or as take-out. Fitness centers, wellness centers, aquaparks, pools, and saunas are closed. High schools must switch to distanced learning. Police may issue ticket up to $€ 1,000$ without warning. In October, a decision was taken to try to test every adult in the country. On 31 October and 1 November tests were undertaken in 5,000 test centers. 2.58 million people tested on Saturday with 25,850 tests being positive. By Sunday evening the testing campaign concluded with more than 3.62 million people tested during the weekend. 38,359 (or $1.06 \%$ ) were positive. Testing was not compulsory but anyone not isolating without a negative test result in a curfew; 19/12/2020 a nationwide lockdown was instituted due to rising numbers of infected and deaths. Except for a few exceptions such as visiting family, going to/from work, buying basic essentials, visiting post offices, banks and doctors, people are required to stay home. The restrictions are planned to last until 10 January $2021 ; 1 / 1 / 2021$, measures were toughened again. The government closed ski centers and churches, prohibited hotels from taking new guests, and visits between different households were prohibited. The restrictions will be in place until 24 January; $8-10 / 1 / 2021$ decision was taken to try to test every adult in city Nitra. Testing was not compulsory but anyone not isolating without a negative test result in a harsher curfew in Nitra, In January, a decision was taken to try to test every adult in the country again. Testing was not compulsory but anyone not isolating without a negative test result in a harsher curfew; 8/2/2021 COVID automat was launched; $1 / 3 / 2021$ measures were toughened again. Curfew was toughened between 8:00 PM and 1:00 AM. All shops were closed at 8:00 PM; 8/3/2021 FFP2 face masks in public transport and shops; 15/3/2021 Compulsory FFP2 face masks in interiors; 20/3/2021 Holidays were prohibited until 28 April; 25/3/2021 Movement in city and nature is only allowed between 5:00 AM and 8:00 PM; 29/4/2021 Movement in city and nature is only allowed between 5:00
AM and 9:00 PM (MDSR, 2020; WIKIPEDIA, 2021; URL 2, 2021).

The first measures activated by the government at the beginning of the pandemic (March 2020) were very strict. The number of positive cases was minimal during this period and the population did not have direct experience with the disease. Positive cases were detected in the state quarantine in the accommodation facility, which had to be completed by residents returning from abroad and later in the home quarantine. The overall discipline to comply with the measures decreased continuously when the lift of the measures was adopted by the government (May 2020). People were more benevolent with the measures. Consequently, the borders were opened and people began to travel on vacation (summer 2020), they spent time in restaurants and pubs, summer terraces, and shopping centers, but the mass events were officially banned. People returning from and on vacation had to spend time in the home quarantine. The overall situation has deteriorated (autumn 2020) and the incidence of the virus in the population has increased. The number of infections and deaths increased (Figure 1) (December 2020 - March 2021). The overall discipline for the population to follow the measures was not optimal, probably, because the population did not have direct experience with deaths from this disease.

\section{The hygiene measures for employees}

By the Resolution of the Government of the Slovak Republic no. 77 (published in the Collection of Laws under number 49/2021) the state of emergency was repeatedly extended, declared by the Resolution of the Government of the Slovak Republic no. 587 of 30 September 2020, for 40 days with effect from 8 February 2021 in the entire territory of the Slovak Republic. At the same time, with effect from 8 February 2021, the government restricted freedom of movement and residence by a ban on going out from 8 February 2021 from 05.00 . until 01.00 the following day, until further notice, but no later than the end of the state of emergency repeatedly extended by this resolution, ie after 19 March 2021, this restriction not applying to travel to and from employment in the case of a person who meets one of the exceptions: Travel to and from the employment, if this person proves a negative result by an RT-PCR test not older than 7 days or an antigen test certified in the territory of the European Union for COVID-19 not older than 7 days, or if the person has a history of COVID-19 and has proof of its survival for not more than three months, or if the person has been vaccinated against COVID-19 with a second dose of vaccine and at least 14 days have passed since that vaccination, or if his or her condition or a medical contraindication does not allow the COVID-19 test to be performed (URL 3, 2021).

At the beginning of March, METRO adopted hygiene, disinfectant and other preventive measures, which are regularly updated. The stores are equipped with disinfection dispensers and stands for use by customers and employees at designated locations. Employees have been instructed to follow all hygiene measures defined by the Public Health Authority of the Slovak Republic or the World Health Organization (WHO). Replacement of air conditioning filters and disinfection of air conditioning was also carried out in all areas (URL 4, 2020). 
METRO employees have protective equipment at their disposal, such as a masks, gloves and disinfectants. At the same time, it demands that its customers respect the wearing of masks or other alternatives in all sales areas and in contact with METRO Distribution employees. "Metro thank all customers who behave responsibly during purchases in our stores, comply with current government regulations and thus protect not only themselves but also our employees," METRO also welcomes the recommendations on responsible purchasing issued by the Slovak Alliance of Modern Trade (SAMO) and encourages customers to continue to follow these rules (URL 4, 2020). Hygiene recommendations have been implemented by all big food retail networks and small shops in the Slovak Republic.

The overview of the Specific COVID-19 pandemic legislation requirements in Slovakia for supermarkets and grocery food stores

Based on public decrees and measures of the Chief Hygienist of the Slovak Republic the following measures concerning the grocery stores are valid in Slovakia. We are providing them in chronological order:

From $25^{\text {th }}$ of March 2020, it is ordered to close all grocery stores including bread, pastries and meat stores, fruit and vegetable stores, grocery stores for special nutritional purposes for infants and young children every Sunday of the month until further notice, and operators are required to disinfect the premises (PHA SR, 2020a).

From $30^{\text {th }}$ of March 2020 according to $\S 48$ par. 4 letter e) of Act no. 355/2007 Coll. of the Slovak Republic for clients and employees the following measures are ordered until the appeal: entry and stay in the store only with the covered upper respiratory tract, to apply a disinfectant on the hands, or to use disposable gloves. Provide $2 \mathrm{~m}$ distance in rows. One customer on $25 \mathrm{~m}^{2}$ of sales area of store. Place the notice in a visible place for buyers at all entrances with the specified hygiene measures for the maximum number of customers at one time. Furthermore, it is ordered from Monday to Saturday, 9:00 to 12:00 to allow entry only to persons over 65 years (PHA SR, 2020b).

From 22 ${ }^{\text {nd }}$ of April 2020, a complement to the previous measures: perform frequent ventilation in the premises and disinfect the contact surfaces, handles, shopping carts, and baskets regularly and wash the floors wet every day. From Monday to Friday from 9:00 am until 11:00 to allow entry only to persons over 65 years of age. The Public Health Authority of the Slovak Republic regulates the reserved purchase time for seniors over 65 years of age from $21 / 04 / 2020$. The currently valid reserved shopping time for seniors over 65 is from 9:00 to 11:00 Monday to Friday (PHA SR, 2020c).

From $6^{\text {th }}$ of May 2020, a complement to the previous measures: the maximum number of customers in store is one customer per $25 \mathrm{~m}^{2}$ of the sales area of the store. This condition does not apply to children (PHA SR, 2020d).

From $2^{\text {th }}$ of May 2020, change of previous measures: the number of customers in store at one time may not exceed the concentration of one customer per $15 \mathrm{~m}^{2}$ of the sales area of the store, which does not apply to children. It is ordered to the operators to provide in the grocery store and drugstore from Monday to Friday from 9:00 to 11:00 entry only for persons over 65 years of age (PHA SR, 2020e).
From $27^{\text {th }}$ of May 2020, from 6:00, change of previous measures. the number of customers in store at any one time shall not exceed one concentration of one customer per 15 $\mathrm{m}^{2}$ of the area of store intended for customers, this condition shall not apply to children; this condition also does not apply if the operator can ensure and maintain a distance between individual customers of at least two meters (PHA SR, 2020f).

From $3^{\text {rd }}$ of June 2020 change of previous measures: in the grocery store there may be no more than one customer per $10 \mathrm{~m}^{2}$ of the sales area of the store, this does not apply to children. The condition also does not apply if the operator allows ensuring a two-meter distance between customers (PHA SR, 2020g).

From $20^{\text {th }}$ of June 2020, complementing previous measures: grocery stores must also ensure the detailed implementation of regular cleaning and disinfection under the daily sanitation regime based on acceptable and established principles of good hygiene practice under Regulation (EC) No 1774/2002 of the European Parliament and the Council. 852/2004 on food hygiene (PHA SR, 2020h).

From $1^{\text {st }}$ of October 2020, change of previous measures: maintaining distances in the row of persons in the store of at least two meters, and this does not apply to persons living in the same household (PHA SR, 2020i).

From $15^{\text {th }}$ of October 2020 change of previous measures: the concentration of one customer per $15 \mathrm{~m}^{2}$ of sales area of the store cannot exceed, but this requirement does not apply to children from 14 years of age with an adult. It is ordered to the operators to provide from Monday to Friday from 9:00 to 11:00 entry only for persons over 65 years of age (PHA SR, 2020j).

From $19^{\text {th }}$ of December 2020 change of previous measures: the concentration of one customer per $15 \mathrm{~m}^{2}$ of sales area of the store cannot exceed, but this does not apply to children under 10 years accompanied by an adult, it is also prohibited for customers to consume food and beverages in indoors and outdoors parts of the store. On Mondays and Fridays from 9:00 to 11:00, entry is allowed only for persons over 65 years of age, except for 24.12. 2020 and 31.12.2020, when the valid shopping time for seniors is from 9:00 to 10:00 (PHA SR, 2020k).

All facility operators are required to ensure that the number of customers in store at a time is one customer per $15 \mathrm{~m}^{2}$ of sales area designated for customers, but this condition does not apply to children under 10 years accompanied by an adult when the area of store intended for customers does not reach $15 \mathrm{~m}^{2}$. A maximum of one customer, except for children, may be in store at any one time. Operators of food stores should allow Monday to Friday from 9:00 to 11:00 entry is allowed only for persons over 65 years of age (PHA SR, 2021a).

From $2^{\text {nd }}$ of February 2021 change of previous measures: according to the provisions of $\S 48$ par. 4 letter c), e) and y) of Act no. 355/2007 of Coll. of the Slovak Republic as amended for the districts of Trnava, Hlohovec, and Pieštany, all facility operators are ordered to comply with the following measures: the number of customers in store at one time may not exceed the concentration of one customer per $25 \mathrm{~m}^{2}$ from the sales area designated for customers, this does not apply to children up to 10 years accompanied by an adult. If the sales area of the store intended for customers 
does not reach $25 \mathrm{~m}^{2}$, then a maximum of one customer can be in store at a time (this condition does not apply to children under 10 years accompanied by an adult). Ensure the maximum possible use of available cash registers to minimize the number of customers waiting in front of cash registers. In the case of self-service cash registers, ensuring that the distances between persons in rows are maintained, including lateral distances of at least $2 \mathrm{~m}$, does not apply to persons living in the same household. To ensure the maintenance of distances between persons in rows of at least $2 \mathrm{~m}$ in the interiors of the store, this does not apply to persons living in the same household (PHA SR, 2021b).

From $8^{\text {th }}$ of March 2021 change of previous measures: according to the provisions of $\S 48$ par. 4 letter c), e) and y) of Act no. 355/2007 of Coll. of the Slovak Republic, it is ordered to all facility operators to comply with the following measures: to ensure the maximum possible use of available cash registers to minimize the number of customers waiting in front of cash registers. In the case of self-service cash registers, ensuring that the distances between persons in rows are maintained, including lateral distances of at least $2 \mathrm{~m}$, does not apply to persons living in the same household. In the interiors of the store to ensure the maintenance of distances between persons in rows of at least two meters, this does not apply to persons living in the same household. According to $\S 48$ par. 4 letter e) of the Act, food business operators are ordered to allow from Monday to Friday from 9:00 am. to 11:00 am. entry only to persons over 65 years of age or persons with severe disabilities and their guides, based on a card of a person with severe disabilities or a card of a person with severe disabilities with a guide (PHA SR, 2021c).

From $15^{\text {th }}$ of March 2021 change of previous measures: according to $\S 48$ par. 4 letter r) of the Act no. 355/2007 of Coll. of the Slovak Republic to properly cover the upper respiratory tract (nose and mouth), all persons are ordered to use a preventive protective device, which is a respirator (not a mask) or similar device (always without exhalation valve) meeting at least all technical conditions and requirements for filter half mask with at least FFP2 classification according to the technical standard STN EN $149+\mathrm{A} 1$. Wearing this kind of respirator is mandatory in the public in all commercial establishments (PHA SR, 2021d).

From 22 ${ }^{\text {nd }}$ of March, 2021, change of previous measures: for the districts of Čadca and Kysucké Nové Mesto, all facility operators are ordered to comply with the following measures: the number of customers in store at one time may not exceed one customer per $25 \mathrm{~m}^{2}$ children up to 10 years of age accompanied by an adult if the sales area of the store intended for customers does not reach $25 \mathrm{~m}^{2}$. At most one customer can be in store at a time. This condition does not apply to children under 10 years accompanied by an adult. Ensure the maximum possible use of available cash registers to minimize the number of customers waiting in front of cash registers. In the case of self-service cash registers, to ensure that the distances between persons in rows are maintained, including lateral distances of at least 2 $\mathrm{m}$, this does not apply to persons living in the same household. In the interiors of the store to ensure the maintenance of distances between persons in rows of at least $2 \mathrm{~m}$, this does not apply to persons living in the same household (PHA SR, 2021e).
In addition to the above requirements when the grocery shop is located in the shopping center: the shopping center should allow access to the premises only to a person with a body temperature of not more than $37{ }^{\circ} \mathrm{C}$, each person entering this shopping center should disinfect hands. Only grocery stores, drugstores, and pharmacies can be open for the public in the department store. Other retail stores must be closed. Only the issue of goods purchased in advance in the e-shop is allowed (PHA SR, 2020k).

In a stricter regime, during the peak of the pandemic, there was a restriction for persons to shop food only in the nearest retail/grocery or similar place from the place of residence to the extent necessary to procure the essential needs of life (in particular the purchase of food, medicine, medical devices, hygiene goods, drugstores goods, feed and other necessities for animals, provision of childcare, provision of care pets, refueling) (PHA SR, 2021f).

From $16^{\text {th }}$ of April, 2021 a) Only persons with covered upper airways may enter and stay in the outdoor and indoor areas of the store; this obligation does not apply to the time required for the consumption of beverages and food, b) apply hand disinfection to entrants or provide disposable gloves at the entrance to the facility, c) visibly place a notice of the obligation to comply with the above hygiene measures on all entrances, to carry out frequent ventilation of the premises and to regularly disinfect contact surfaces, handles, shopping carts and baskets, used devices, tools and aids, to use disinfectants with viruidal effect for disinfection, e) to ensure that the distance between persons is at least $2 \mathrm{~m}$; this does not apply to persons living in the same household or persons with severe disabilities and their assistants, f) the number of customers in store at one time may not exceed the concentration of one customer per 15 $\mathrm{m}^{2}$ of the sales area of the establishment intended for customers; this does not apply to children under 10 years accompanied by an adult; if the sales area of the place intended for customers does not reach $15 \mathrm{~m}^{2}$, there may be a maximum of 1 customer in the place at one time; this condition does not apply to children under 10 years of age accompanied by an adult, $g$ ) the obligation under letter $f$ ) is met if the area of store intended for customers does not reach $90 \mathrm{~m}^{2}$.

All operators of department stores, where a department store is considered to be a defined enclosed space, permanent architectural object, which consists of a set of shops or premises intended for services and sales of goods, observe the following measures: a) equip the hygiene facilities of the store with liquid soap and paper towels, b) allow entry to the premises of the department store only to a person with a body temperature of $37^{\circ} \mathrm{C}$, c) the number of customers in the department store at one time must not exceed one customer per $15 \mathrm{~m}^{2}$ of sales area of all operations in the department store intended for customers; this condition does not apply to children under 10 years of age accompanied by an adult, d) to disinfect sanitary facilities every hour, e) to ensure that public catering establishments serve food and drink only in the packaged state, $f$ ) it is forbidden to consume food and drinks in the premises of the department store, g) ensure the closure of seating sections and children's corners (PHA SR, 2021g). 


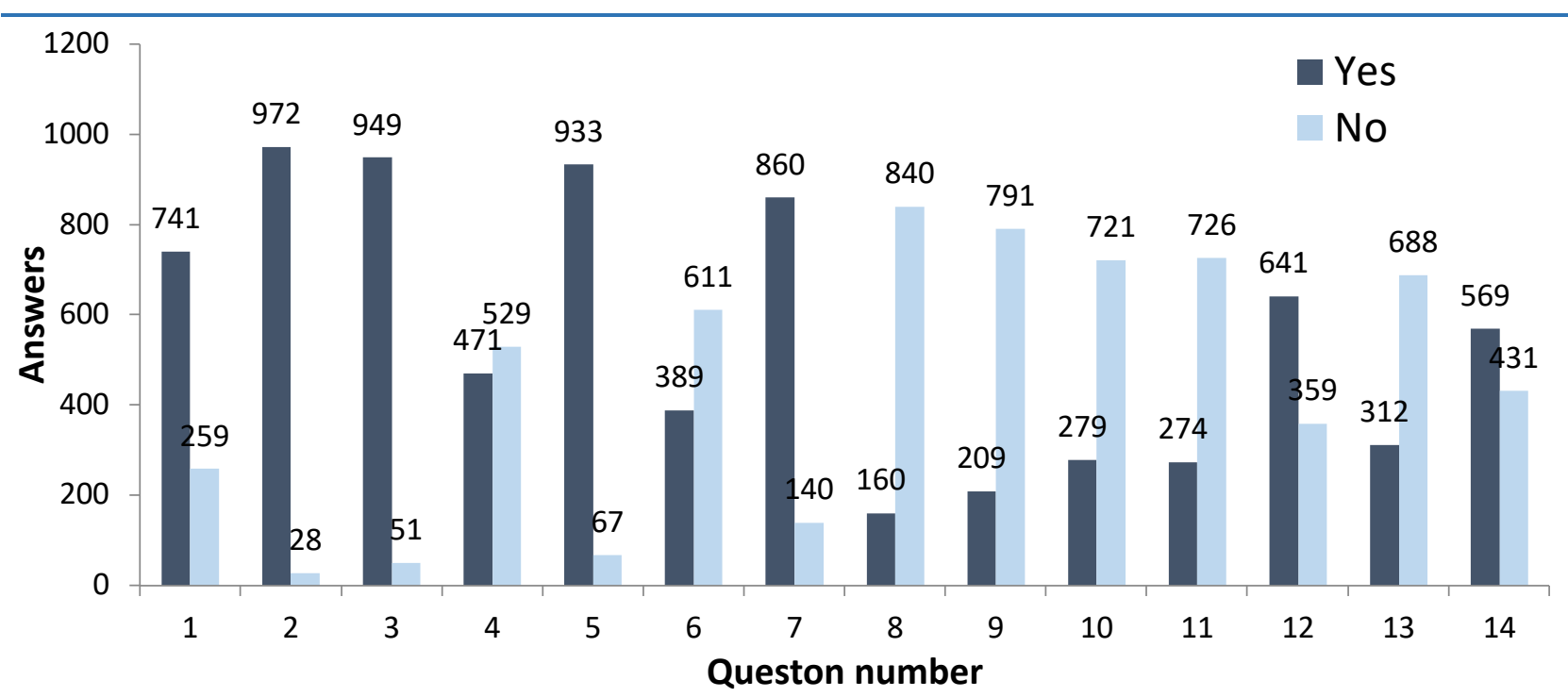

Figure 5 Results of the questionairy survey (number of respondents $=1,000$ ).

Gradually, in connection with the improvement of the pandemic situation in May 2021, the lift of the measures is expected. Other stores in shopping centers are opening again. The sale of food in markets and marketplaces is resumed.

\section{Results of the hygiene measures questionary survey}

The COVID-19 pandemic situation has changed the behavior of the population living in the Slovak Republic from many aspects of human life. It is well known, that the diverse site of the pandemic covers the loss of human lives, negative health impacts, negative economic aspects, etc. The shopping ability was driven by mentioned facts but also by several regulations that prohibit entrance to most of the shops and other typical services, with a few exceptions for groceries, drug, pharmacy or pet feed shops, with one general goal to minimize the close human contacts to slow down spreading of the virus. Remarkable was increased interest for food-like stuff, probably caused by the higher need for cooking activities caused by home office isolation, transferred to a higher frequency of grocery shops visiting. As such places are risky from the COVID-19 human-tohuman share point of view for a long time, we have prepared the questionary with a package of fourteen questions focused on the most important anti-Covid regulations and routines to maintain a picture of real anti-pandemic customer protection in the Slovak market. One thousand respondents fill out the online questionnaire, on the principle of one choose answer per each question, based on Yes or No. Results of the hygiene measures survey are presented in Figure 5 and Figure 6.

\section{Questions:}

1. Do you think that COVID measures in stores are sufficient? 741 Yes, 259 No

2. Was there a notice regarding the hygiene measures for customers in connection with COVID-19 before entering the store (picture, text)? 972 Yes, 28 No

3. Was there a disinfectant for customers before entering the store? 949 Yes, 51 No

4. Does the seller disinfect baskets and carts? 471 Yes, 529 No
5. Do customers have disposable gloves available for handling unpackaged products? 933 Yes, 67 No

6. Do you think that the frequency of disinfection of areas with which customers come into direct contact is sufficient (handles and handles on refrigerators/freezers, pastry tongs, belts on cash registers, etc.)? 389 Yes, 611 No

7. Was the overall cleanliness in the store satisfactory? 860 Yes, 140 No

8. Is the observance of distances between customers in the store premises checked in the store? 160 Yes, 840 No

9. Is the observance of the spacing in the rows at the cash registers checked? 209 Yes, 791 No

10. Have you encountered a situation where a person of a younger age category was present in the store during the time set aside for the purchase of seniors from 9:00 to 11:00? 279 Yes, 721 No

11. Did you witness that the staff or customer did not have an FFP2 respirator in the store? 274 Yes, 726 No

12. Did you witness that the staff or customer did not have a properly fitted respirator in the store? 641 Yes, 359 No

13. Do you use the service of buying goods by delivery directly to your home? 312 Yes, 688 No

14. Do you only pay for your purchase with a payment card? 569 Yes, 431 No

We have performed the statistical analysis of the questionnaire survey. When using multiple correspondence analysis (MCA), we assume that we will plot a substantial part of the information from the obtained study data using two or more axes. Multiple correspondence analysis on the data obtained from the questionnaires extracted a total of 22 dimensions, which characterized the respondents' answers to $100 \%$. The first dimension represented $12.75 \%$, the second dimension $8.09 \%$, and the third $7.62 \%$ of the total variation of the data $100 \%$. The first two dimensions together characterized the respondents' answers to $20.84 \%$ (Figure 1). The graph shows age, gender, and education. 
Table 1 Results of the multiple correspondence analysis of the questionairy survey.

\begin{tabular}{cccccc}
\hline \multicolumn{2}{c}{ Dimension 1 } & \multicolumn{2}{c}{ Dimension 2 } & \multicolumn{2}{c}{ Dimension 3 } \\
\hline Questions & $\boldsymbol{p}$-value & Questions & $\boldsymbol{p}$-value & Questions & $\boldsymbol{p}$-value \\
\hline Q9 & $4.917 \mathrm{E}-138$ & Age & $3.283 \mathrm{E}-79$ & Age & $6.148 \mathrm{E}-121$ \\
Q8 & $1.262 \mathrm{E}-135$ & Q14 & $4.092 \mathrm{E}-68$ & Q10 & $2.271 \mathrm{E}-91$ \\
Q6 & $8.561 \mathrm{E}-106$ & Q13 & $1.624 \mathrm{E}-51$ & Gender & $1.449 \mathrm{E}-50$ \\
Q12 & $2.600 \mathrm{E}-83$ & Q4 & $1.301 \mathrm{E}-49$ & Education & $4.773 \mathrm{E}-45$ \\
Q7 & $1.620 \mathrm{E}-60$ & Education & $7.466 \mathrm{E}-43$ & Q1 & $2.787 \mathrm{E}-34$ \\
Q1 & $4.424 \mathrm{E}-53$ & Q7 & $4.552 \mathrm{E}-41$ & Q12 & $3.760 \mathrm{E}-25$ \\
Q11 & $1.984 \mathrm{E}-52$ & Q12 & $5.809 \mathrm{E}-29$ & Q11 & $5.357 \mathrm{E}-21$ \\
Q4 & $3.221 \mathrm{E}-50$ & Q1 & $4.099 \mathrm{E}-22$ & Q4 & $6.544 \mathrm{E}-19$ \\
Vek & $1.909 \mathrm{E}-47$ & Q10 & $4.316 \mathrm{E}-21$ & Q5 & $1.099 \mathrm{E}-16$ \\
Q3 & $3.192 \mathrm{E}-10$ & Q2 & $9.062 \mathrm{E}-15$ & Q13 & $8.099 \mathrm{E}-04$ \\
Q5 & $5.030 \mathrm{E}-07$ & Q6 & $7.071 \mathrm{E}-12$ & Q6 & $4.258 \mathrm{E}-03$ \\
Education & $2.332 \mathrm{E}-05$ & Q11 & $1.560 \mathrm{E}-10$ & Q2 & $4.864 \mathrm{E}-03$ \\
Q14 & $6.154 \mathrm{E}-05$ & Q3 & $3.364 \mathrm{E}-03$ & Q9 & $6.954 \mathrm{E}-03$ \\
Q2 & $8.731 \mathrm{E}-05$ & & & Q8 & $3.600 \mathrm{E}-02$
\end{tabular}

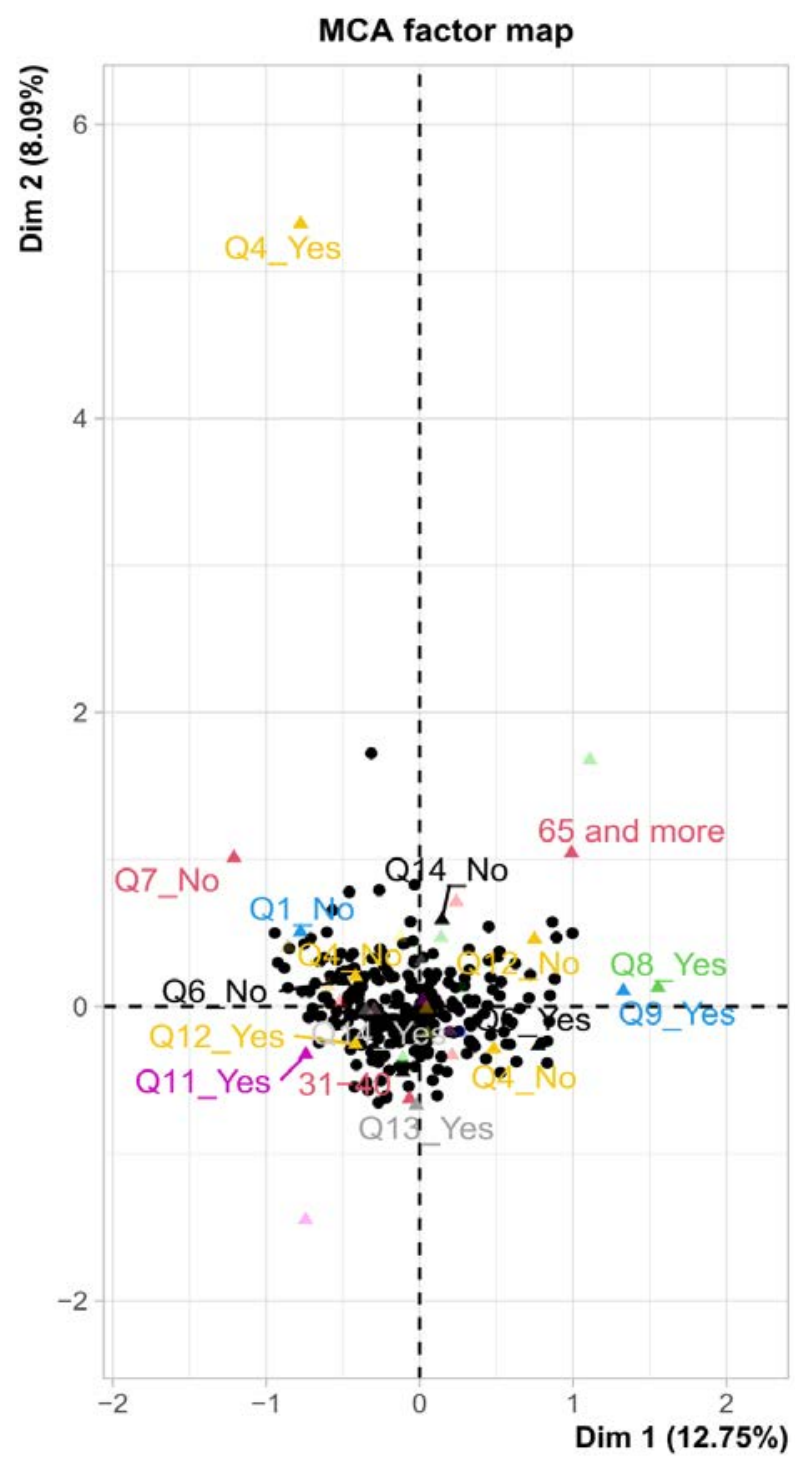

Figure 6 Results of multiple correspondence analysis (MCA) of the first two dimensions. 
The most statistically significant at the level of significance $p<0.05$ (Table 1) was characterized by the following questions with the percentage of answers on the internal characteristic of the dimension: Q9 (Yes $=13.14 \%$; No $=$ $3.48 \%)$; Q8 (Yes $=13.78 \%$; No $=2.63 \%)$; Q6 $($ Yes $=$ $8.28 \%$; No $=5.28 \%)$; Q12 $($ Yes $=4.00 \%$; No $=7.16 \%)$; Q7 $($ Yes $=1.17 \%$; No $=7.27 \%) ;$ Q1 $($ Yes $=1.94 \% ;$ No $=$ $5.56 \%)$; $11($ Yes $=5.38 \mathrm{No}=2.03 \%) ; \mathrm{Q} 4(\mathrm{Yes}=3.88 \%$; No $=3.31 \%)$; Q3 (Yes $=0.07 \%$; No $=1.32 \%)$; Q5 (Yes $=$ $0.06 \%$; No $=0.83 \%)$; Q14 $(\mathrm{Yes}=0.25 \%$; No $=0.32 \%)$; Q2 $($ Yes $=0.01 \% ;$ No $=0.53 \%) ; \mathrm{Q} 10($ Yes $=0.17 \%$; No $=$ $0.07 \%)$. For second dimension: Q14 (Yes $=6.36 \%$; No $=$ $8.42 \%)$; Q13 (Yes $=7.91 \%$; No $=3.59 \%)$; $\mathrm{Q} 4(\mathrm{Yes}=$ $2.17 \%$; No $=1.23 \%)$; Q7 (Yes $=1.29 \%$; No $=8.00 \%)$; Q12 $($ Yes $=2.37 \%$; No $=4.24 \%)$; $11($ Yes $=1.30 \% ;$ No $=$ $3.73 \%)$; Q10 (Yes $=3.45 \%$; No $=1.34 \%) ; \mathrm{Q} 2(\mathrm{Yes}=$ $0.09 \%$; $\mathrm{No}=3.20 \%)$; Q6 (Yes $=1.58 \%$; No $=1.01 \%)$; Q11 $($ Yes $=1.64 \%$; No $=0.62 \%)$ a Q3 $($ Yes $=0.02 \% ;$ No $=$ $0.46 \%$ ). Dimension 3 is characterized by the following questions with a percentage of responses: Q10 (Yes = $14.53 \%$; No $=5.63 \%)$; Q1 $(\mathrm{Yes}=2.14 \%$; No $=6.15 \%)$; Q12 $($ Yes $=2.18 \%$; No $=3.91 \%) ;$ Q11 $($ Yes $=3.68 \% ;$ No $=$ $1.39 \%)$; Q4 (Yes $=0.02 \%$; No $=0.13 \%)$; Q5 (Yes $=0.26 \%$; No $=3.72 \%)$; Q13 (Yes $=0.46 \%$; No $=0.21 \%)$; Q6 (Yes = $0.30 \%$; No $=0.19 \%) ; \mathrm{Q} 2(\mathrm{Yes}=0.01 \%$; No $=0.17 \%) ; \mathrm{Q} 9$ $($ Yes $=0.34 \%$; No $=0.09 \%)$ a Q8 $($ Yes $=0.22 \%$; No $=$ $0.04 \%)$.

Our questionnaire survey shows that most respondents think that the hygiene measures implemented in stores are sufficient in Slovakia. Almost one-third of the respondents believe that these measures are not sufficient, resp. could fail.

Almost all respondents stated that they were informed about the obligation to comply with hygiene measures in the form of a visual notice, a pictogram, before entering the store. However, some respondents stated that some notices were in a visually inaccessible place or were difficult to read.

Almost all respondents stated that they had a disinfectant available before entering the store. In some cases, the sellerprovided a device for hand disinfection, but there was no disinfectant in this device, respectively this device was not refilled again.

More than half of respondents believe that the store does not disinfect shopping carts and baskets. Many respondents did not see any of the service staff to do baskets and shopping carts disinfection.

Therefore, many respondents used their disposable gloves and their disinfectant as a precaution or increased the dose of disinfectant when entering the store and with wet hands caught the handle of the basket or trolley.

Almost all respondents stated that the seller-provided disposable gloves for handling non packaged food such as bakery products. However, in some answers, they stated that disposable gloves were missing, resp. was not close to the food.

More than half of the respondents believe that the frequency of disinfection of surfaces with which they come into contact in the store and hand-held devices (handles and handles on refrigerators/freezers, pastry tongs, belts on cash registers, etc.) is insufficient.

Most respondents think that the overall level of cleanliness in stores is satisfactory.
Most respondents have experienced that there is no supervision of compliance with mandatory distances between customers.

Most respondents have experienced that there is no supervision of compliance with mandatory distances between customers waiting in line in front of the cash registers.

Many respondents have encountered a situation where a person of a younger age category was present in the store during the time set aside for the purchase of seniors from 9:00 to 11:00.

Many respondents have experienced that the staff or customer did not wear a respirator of FFP2 class. According to the comments, this problem mainly concerns customers.

Also, even more, respondents stated that the staff or customer did not have a properly fitted respirator in the store.

Almost two-thirds of respondents do not use the online service to buy food goods and their delivery directly to the home. Some consumers could not buy food online because their favorite retailer did not offer such an option. There were only two big food retailers who operated such a service in Slovakia for consumers.

More than half of customers prefer payment by credit card when making a purchase. However, many consumers also want to continue to pay in cash.

\section{Opinions of respondents}

The most frequent answers of the respondents included the following:

There should be a competent person (security man) at the entrance who will supervise the use of disinfectant because it has already been abandoned. Reduce the number of customers. Observe the spacing. Pensioners should shop only for limited hours and not go to the store whenever they want, they would be more protected. Gloves could also be mandatory. More frequent disinfection of trolleys, bag racks, etc.), limits the capacity of people (or control it). More frequent disinfection of surfaces with which customers come into contact. More frequent cleaning of shopping baskets. The disinfection of shopping carts and baskets is inconsistent. Disinfection of trolleys, gloves, distances is not observed! Observe the number of people per $1 \mathrm{~m}^{2}$. More thorough control of hand disinfection. A more thorough inspection of properly fitted respirators/masks. Make sure everyone has the mask in place properly. Disinfect even more often and often check if people have anything to disinfect their hands with. Checking compliance with the measures. Checking antigen or PCR tests before entry, disinfection of the basket at entry. Disinfect baskets and trolleys, consistently release retirees only in the allotted time. I have a feeling that shopping carts are not disinfected at all. Fewer people at the store and more frequent disinfection of shopping baskets, often missing a disinfectant in the store. Temperature measurement in people before entering the store, disinfection of baskets after each use, disinfection of door handles at least once every 15-20 minutes. People manipulate with bare hands with unpackaged bread, vegetables, fruit and no one will warn them. Insufficient disinfection of areas such as cash registers, handles, baskets, pastry tongs. Insufficient hygiene measures for manipulation with pastry, fruit, and vegetables, insufficient hygiene for the cash register, for 
handling goods and money. Negative tests are not checked, insufficient disinfection of baskets, door handles, the permitted number of people per square meter is not observed, poor disinfection of the hands of saleswomen at the cash register. I don't think that disinfection at the entrances is sufficient, I often find it diluted, people just apply it to their hands in a proforma so that it doesn't happen. Someone should stand at the entrance, they could encourage customers to better disinfect. I don't like that there is no limited number of customers in supermarkets, and so often, especially in the fruit and pastry section, there is a so-called head to head. The number of people per area is not observed. There are no controls, people do not use disinfectant, they rummage in pastries without gloves. The controls are simply not satisfactory, traders don't care, mainly to sell the goods. I've never seen saleswomen disinfect handles, baskets. Staff who control the number of people and hand cleaning and negative tests are missing, people have no respect, they do what they want. In my opinion, everyone should put on their gloves before entering the store and throw them away at the end. Mandatory gloves. The saleswomen have a mask under their noses and the temperature and the number of people are no longer checked, and people stand in a long line. Tighter regulation of the number of customers and control of valid measures. Stricter controls in stores. Who controls them at all? How is it possible that the measures are not complied with? People infected with the corona also have access to shops (and they know about it), it doesn't feel right to me. I don't even see the logic in the time reserved for retirees, so if they have to go to the shops in a reserved interval, then they should not go when others can go. Regulation of the number of people in the store. Weak control of a limited number of people per $\mathrm{m}^{2}$. Monitoring of distances, no one checks it directly in the store. Stricter controls. Theoretically, they may be sufficient, but I rather see the problem in the customers themselves. In my experience, no one cared how many people entered the store. No one checked to see if people were disinfecting their hands. People did not keep a minimum distance of $2 \mathrm{~m}$ and many of them did not have the mask/respirator properly fitted. Crowds in the store at the cash register. People are also very close to pastries. The measures have already been relaxed, no one in the hypermarkets controls the numbers of people, does not clean the baskets, does not measure the temperature as in the beginning. There is disinfection in every store at the entrance, but few people use it, the same for masks and respirators, many people have not properly fitted them on their faces. In a few stores, someone oversees the number of people in the business or at least the proper wearing of a respirator, sometimes disinfection is not available at the entrance. First and foremost, regular disinfection should be added upon entering the store. A lot of people are buried, someone is still breathing down my neck, especially with vegetables in our store, or even with pastries or meat products. And sometimes I don't know if I have a disinfectant to squeeze my hands or feet, they have it differently everywhere. Lots of people in the same place. It would be good to cancel the hours for retirees. A large number of people in the store at the same time, young people between 9-11 can not go to the store but retirees can still (without insult). Get back to normal. No need to do such checks anymore, it is unnecessary. Few checks are performed. The employees are also in the front line and no one cares about them, and people still open their mouths when they reprimand them for their divorce. People get angry and frustrated at the saleswomen because they have to stick to the motto of our customer, our master. Closing operations is nonsense, it would be enough if people were waiting outside and there were only a few people in the store. Grouping of people on stock goods, no spacing $2 \mathrm{~m}$ apart if something is in action and few people are pushing each other. Increase the number of employees to check compliance with hygiene measures. One-way entry and exit are not provided by all retail chains in Slovakia.

The differences in the use of pictograms can be seen in the following figures: Billa supermarkets (Figure 7), Kaufland supermarkets (Figure 8), Tesco supermarkets (Figure 9), Tesco online shopping and delivery (Figure 10), Lidl supermarkets (Figure 11) Coop Jednota (Figure 12). Hygiene measures can be seen in the following figures: Coop Jednota and Tempo (Figure 13 and Figure 14), customers waiting in lines in front of stores (Figure 15), information notices in Tesco (Figure 16), measuring the temperature of people (Figure 17), hygiene measures in Lidl (Figure 18), Tesco (Figure 19), Tesco home delivery (Figure 20), restrictions on the purchase of non-foodstuffs (Figure 21). The Public Health Authority of the SR took over the official leaflet of the World Health Organization, translated it into Slovak, and made it available for download on its website (Figure 22). Several activities and inspections of compliance with regulations were performed by the police of the Slovak Republic and the municipal police in individual cities (Figure 23). Obligation to comply with measures in supermarkets Kaufland (Figure 24). Measures for customers in Metro (Figure 25). Problems with compliance with hygiene measures were regularly observed (Figure 26). Recommendation for one-way movent and disinfection (Figure 27).

The government took strong containment measures to prevent the spread of COVID-19 with restrictions on daily living such as social distancing and the closing of businesses and schools. While these measures are essential to stop the virus from spreading, several voices came to warn of their potentially disruptive impact on the agri-food system (Hassen, El Bilali and Allahyari, 2020), supermarkets, retail food stores, and grocery.

Governments have various other issues to address, such as enforcing the proper lockdown among the people; providing the citizens with basic necessities like food, groceries, and vegetables, from the retailers; enforcing and monitoring law and order during the lockdown period pertaining to areas like transportation, markets, shops, public gatherings, and medical facilities; and identification and treatment of people suffering from coronavirus attack (Jain, Puri and Jain, 2021). We agree that such measures must enable the population to buy food and necessities, including medicines. The measures themselves must therefore not be very restrictive, they must represent a healthy compromise between the needs of the people and the anti-pandemic commissions and public authorities.

Coronavirus disease 2019 (COVID-19) poses an occupational health risk to food system workers including farmers/producers, grocery store workers, emergency food system staff and volunteers (e.g., food pantry workers), and others. 

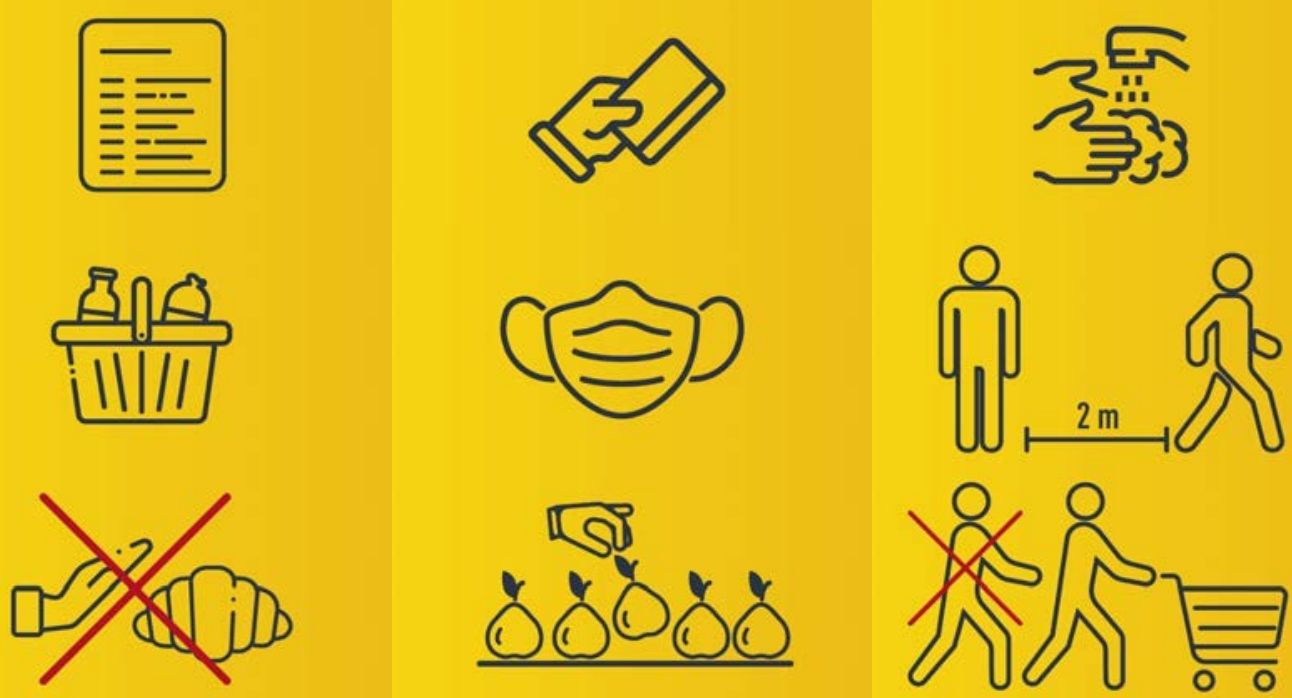

Figure 7. Pictograms in Billa supermarkets, Slovakia (Source: billa.sk).

Note: 1. Shopping list (Before you come to our store to shop, prepare a shopping list so that you do not stay in the store more than necessary). 2. Shop yourself (Go shopping yourself, in less frequent hours (usually between $1 \mathrm{pm}$ and $5 \mathrm{pm}$ )). 3. Protect yourself and others. Wear a mask, scarf or shawl, don't forget the gloves. 4. Keep a distance (Keep a distance of at least 2 meters from the others). 5. Wear gloves (Do not pick up fresh products with bare hands, use disposable gloves). 6 . Think of loved ones (If possible, buy from others - parents, grandparents or neighbors). 7. We replenish the goods (We continuously replenish the goods for you, please buy in moderation). 8. Pay by card (Prefer payment by credit card). 9. Take care of hygiene (Wash your hands thoroughly with warm water and soap after purchase).

Note: Upon entering stores, we will not check customers for a negative test for COVID-19. Thank you for following these basic shopping rules.

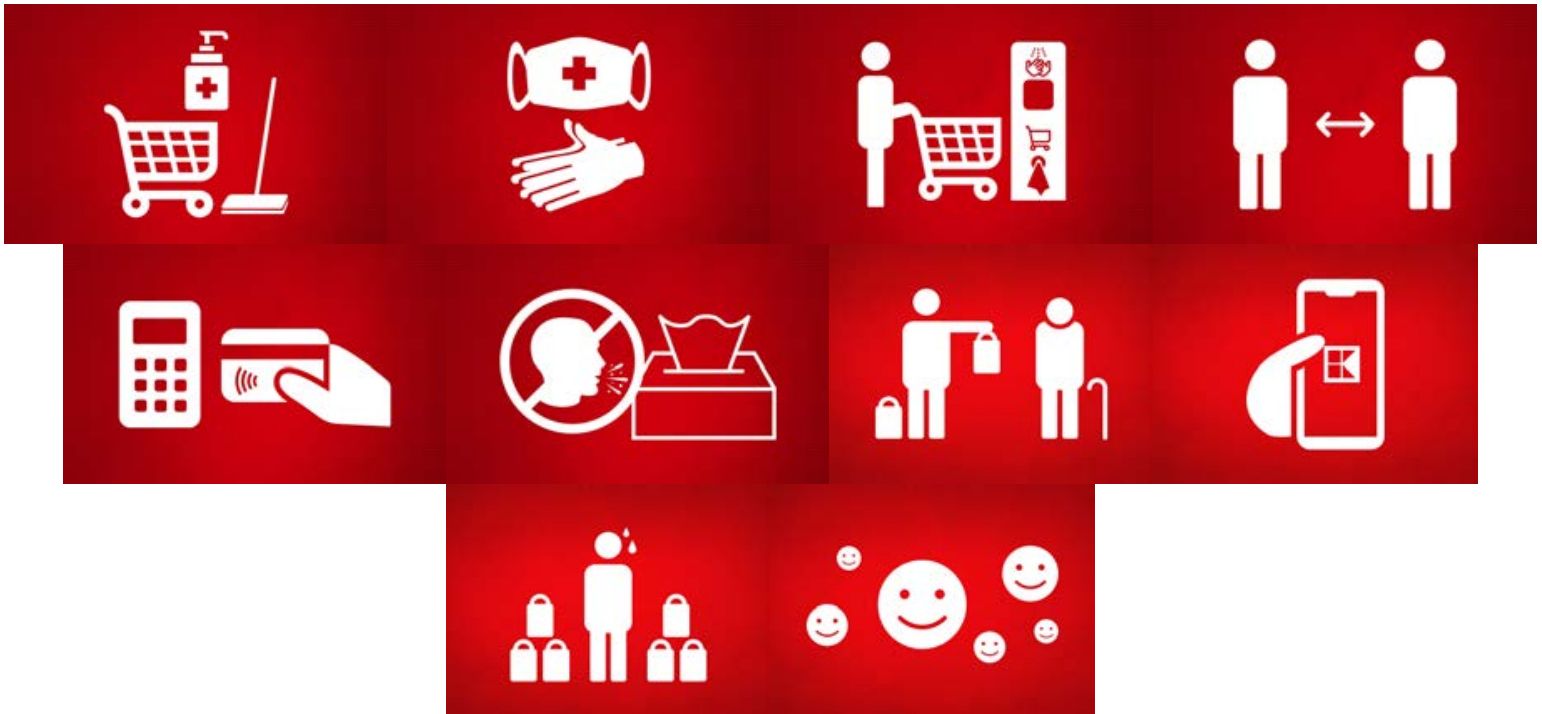

Figure 8. Pictograms in Kaufland supermarkets, Slovakia (Source: kaufland.sk).

Note: 1. Disinfection is very important in the fight against the virus. We also try to protect you, so we intensively clean and disinfect shopping carts and baskets. 2. When shopping, it is necessary to continue to wear a mask, ideally also gloves, and thus protect yourself and others. 3. You can disinfect the handle of the trolley or shopping cart yourself. Use our disinfection station, located at the entrance to the stores. This will reduce the risk of disease transmission. 4. Keep a safety distance of 2 meters between each other - In stores but also in private. This will prevent the spread of droplet infection. 5. Paying with a card means protecting yourself. Payment by smartphone is even more hygienic, as there is no need to enter a PIN code on the terminal. The fewer touches, the lower the risk of infection. 6 . When coughing and sneezing, be sure to cover your mouth and nose thoroughly. Dispose of the handkerchief in a closed basket as soon as possible after use. 7. Especially the elderly and the sick need our help and support right now. If you have an older person in the immediate vicinity, you can possibly make a purchase. Observe precautionary measures in case of personal contact. 8. In addition to distributing leaflets to mailboxes, you will find the current offer in stores and still on our website, in the K-App or in the Newsletter. 9. Only through coherence and consideration can we prevent the spread of the virus together. That is why it is important to think not only about ourselves, but also about our fellow citizens. Valid: less "I", more "we"! 10. Let's be considerate and friendly to each other, despite the current situation. We try to do our best to cope with the difficult situation. We can do it together! 


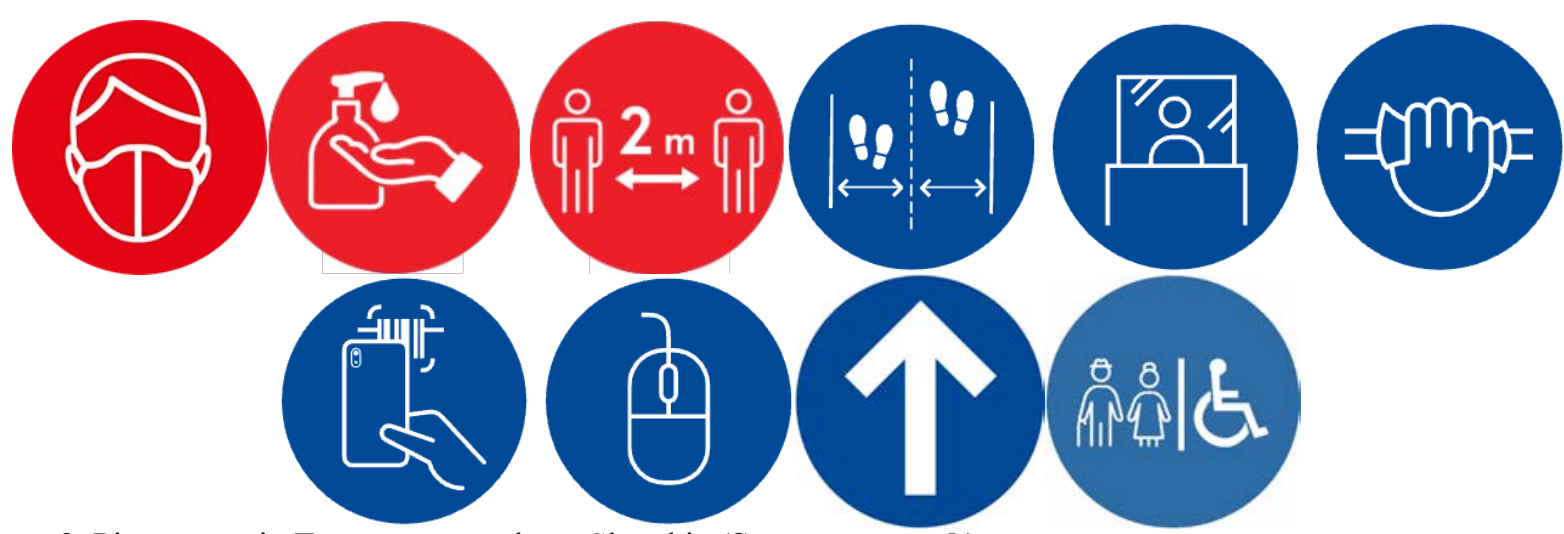

Figure 9. Pictograms in Tesco supermarkets, Slovakia (Source: tesco.sk).

Note: 1. Respirator. Enter the store only with a respirator of class FFP2 and higher. It is necessary to have a covered nose and mouth with a respirator during the entire purchase. 2. Disinfect your hands. Thoroughly disinfect your hands when entering the store. For greater safety, we also recommend using protective gloves. 3. Keep safe distances. Keep a distance of at least 2 meters from other people in the store. 4 . Wide alleys for greater safety. The alley in our stores are wide enough, thanks to which you can be sure that the safe zone and two-meter distances between all shoppers will be observed. 5. Cash registers protected by plexiglass. Protective plexiglass is installed in our stores to protect the health of all shoppers and our colleagues. Thanks to them, we can limit the contact of shoppers with our colleagues to the necessary minimum and you can safely complete your purchase. 6 . Regularly disinfected baskets. We also don't forget to disinfect the store, which also includes shopping carts and baskets. We regularly disinfect them with a hygienic product that effectively protects against viruses and bacteria. 7. Contactless Scan \& Shop service. If you want to shop fast and even safer, you can also use the Scan \& Shop service with us and buy with a mobile phone or scanner. You can put the scanned products directly into your shopping bags, so you no longer have to unload your purchase at the checkout. 8. Convenient ONLINE shopping. If you want to shop from the comfort of your home, at Tesco we offer online delivery of food and other products thanks to the Tesco Online shopping service. We will deliver the food to your first door in compliance with the strictest safety measures. 9. One-way purchase. 10. Seniors and the severely disabled belong to the most vulnerable group. Priority shopping hours protected their health.

Note: Please keep in mind that our employees also have families at home that they care about. These measures protect not only you but also them. The current situation is not easy for any of us, but we assure you that we do everything in our power to bring you a safer purchase every day.
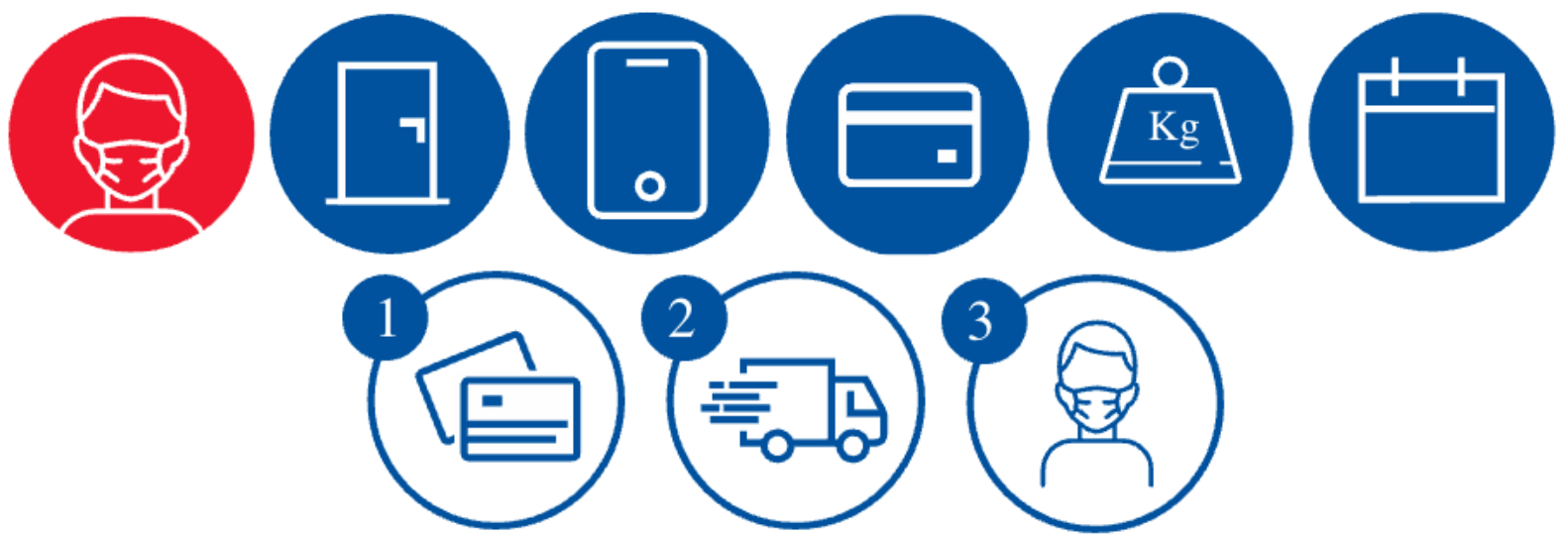

Figure 10. Pictograms: Tesco Online shopping and delivery, Slovakia (Source: tesco.sk).

Note: Pictograms: 1. Wearing a protective mask (Please wear a protective mask on your face during the purchase). 2. Delivery only for the first lockable door (In order to maintain a safe distance, we now deliver the purchase only to the first lockable door). 3. Valid phone number (Please check if you have the current phone number in your Tesco account). 4. Please prefer online payment (If possible, please choose online payment to limit personal contact). 5. Maximum order size (Orders are limited to avoid excessive purchases. We'll notify you on the page when this limit is reached). 6 . Delivery time reservation (We recommend that you book your delivery time in good time, you can complete your purchase later). 7. Online payment is convenient, simple, fast and more secure. 8. Payment for the purchase is charged to you only after receipt of the goods. 9. Contact with the driver is reduced, helping us to minimize the potential spread of the virus.

Note: Dear customer, we would like to inform you that from 3 March 2021 until further notice, the collection of food with the Click + Pick up service will only be possible until 20:00. We value your trust and thank you for respecting all measures that contribute to greater security of delivery and help protect you and our drivers. We do everything to ensure you the most convenient and secure online shopping. During the preparation and delivery of purchases, we observe the strictest hygiene measures - from the use of drapes and disinfection to maintaining a safe distance. For this reason, we now only deliver your purchases to the first lockable door, and we recommend that you prefer to pay online. Before delivery, the driver will contact you to agree with you on the delivery details according to your ideas. In order to best handle the current situation together, we would like to ask you to follow the instructions below. Please take a moment to find out how you can shop safer online these days.

Note: Why do we deliver all purchases in bags? We currently deliver each purchase in bags to meet hygiene standards. In the order, you can choose the delivery of goods in either plastic or paper bags for an additional fee. Please do not return plastic bags to our driver, as we are currently unable to accept them. Thank you for understanding. Why is it better to prefer online payment? We appreciate your choosing to pay for your orders online. It helps us reduce personal contact and keep your shopping as safe as possible.

Note: Important information for home quarantined customers. When taking over the purchase, it is important to strictly observe the above rules, which will prevent the spread of the disease. We want to deliver the goods to you as safely as possible, even if you are currently in quarantine. In order for us to succeed and at the same time be able to protect your health as well as the health of our drivers, we ask you to follow a few simple steps. In the order note, please inform us in advance that you are in home quarantine. We only accept online payments for your orders. We are very sorry, but if you are in quarantine and require payment at the door, your order may be canceled. If our driver contacts you to agree on a suitable method and place of delivery, please inform him that you are in quarantine. Please choose bagged delivery when ordering to minimize personal contact when picking it up. Thank you for following the rules that help us provide our service to as many customers as possible. 


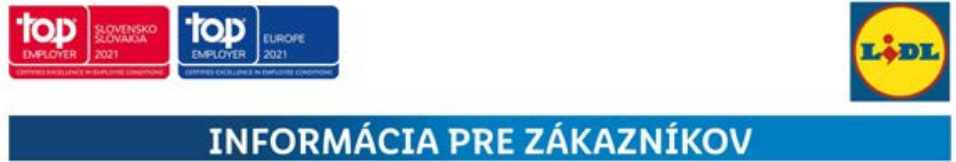

Vážení zákazníci,

v súvislosti so šírením koronavírusu vás prosíme,

aby ste dodržiavali nasledujúce preventívne opatrenia.

Povinnost́ nosit respirátor alebo obdobný prostriedok

v predajni (vždy bez výdychového ventilu) naplňujúci

minimálne všetky technické podmienky a požiadavky

pre filtračnú polomasku s klasifikáciou najmenej FFP2. Použivajte dezinfekciu, ktorú sme pre Vás pripravili
v predajni.

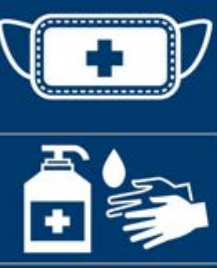

Od pondelka do piatka je v predajni od 9:00 do 11:00 vyhradený nákupný čas pre seniorov nad 65 rokov, osoby ZT̄P a tiež ich asistentov na základe predloženia príslušného preukazu.

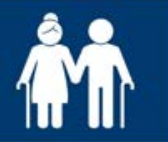

Uprednostruujte bezhotovostné platby.

Rukami sa nedotýkajte tváre, pier, nosa a oči.

Dodržujte bezpečnostnú vzdialenost́ medzi sebou
2 metre.
$\begin{aligned} & \text { Pri manipulácii s nebaleným pečivom použivajte } \\ & \text { jednorazové rukavice. }\end{aligned}$

\section{Dakujeme za pochopenie a ohl'aduplnost' \#pomozmesinavzajom}

Figure 11. Pictograms in Lidl supermarkets, Slovakia (Source: lidl.sk).
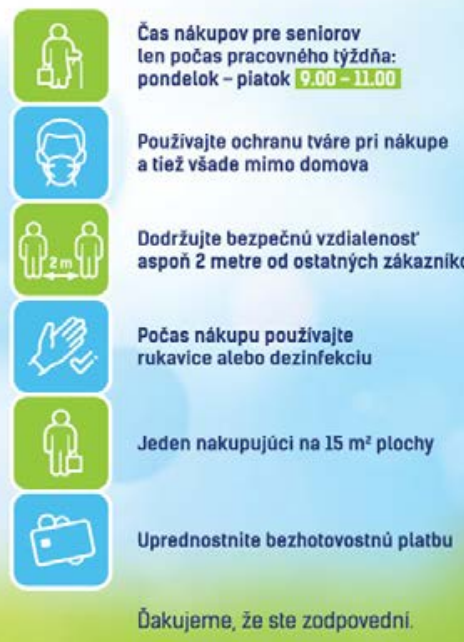

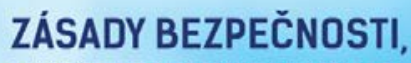
HYGIENY A PREVENCIE
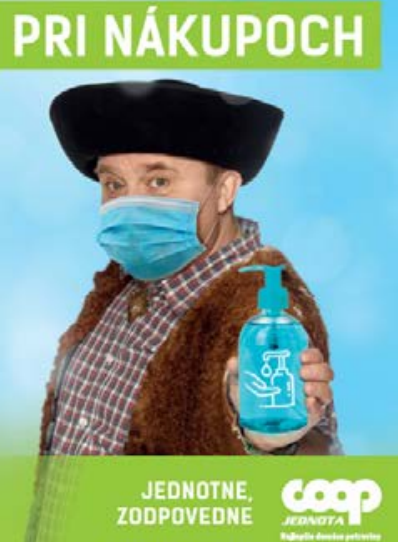

Translation of text:

INFORMATION FOR CUSTOMERS

Dear customers.

In connection with the spread of coronavirus, please follow the following precautions.

Obligation to wear a respirator or similar device in the store (always without an exhalation valve) meeting at least all technical conditions and requirements for a filter half mask with a classification of at least FFP2.

Use the disinfection that we have prepared for you in the store.

From Monday to Friday, shopping time is reserved in the store from 9:00 to 11:00 for seniors over 65, people with disabilities, and their assistants on the presentation of the relevant card.

Prefer cashless payments.

Do not touch your face, lips, nose, or eyes with your hands.

Keep a safe distance of 2 meters between each other.

Use disposable gloves when handling unwrapped pastries.

Thank you for your understanding and consideration \#let'shelpeachother

Figure 12. Pictograms in Coop Jednota, Slovakia (Source: Coop Jednota).

Shopping time for seniors only during the working week: Monday - Friday $9.00-11.00$

Use face protection when shopping and also everywhere away from home.

Keep a safe distance of at least 2 meters from other customers.

Use gloves or disinfectant during the purchase.

One shopper per $15 \mathrm{~m}^{2}$ area.

Prefer cashless payment.

Thank you for being responsible.

Note: Principles of safety, hygiene, and prevention when shopping. Uniformly and responsibly Coop Jednota. The best homemade food store. 


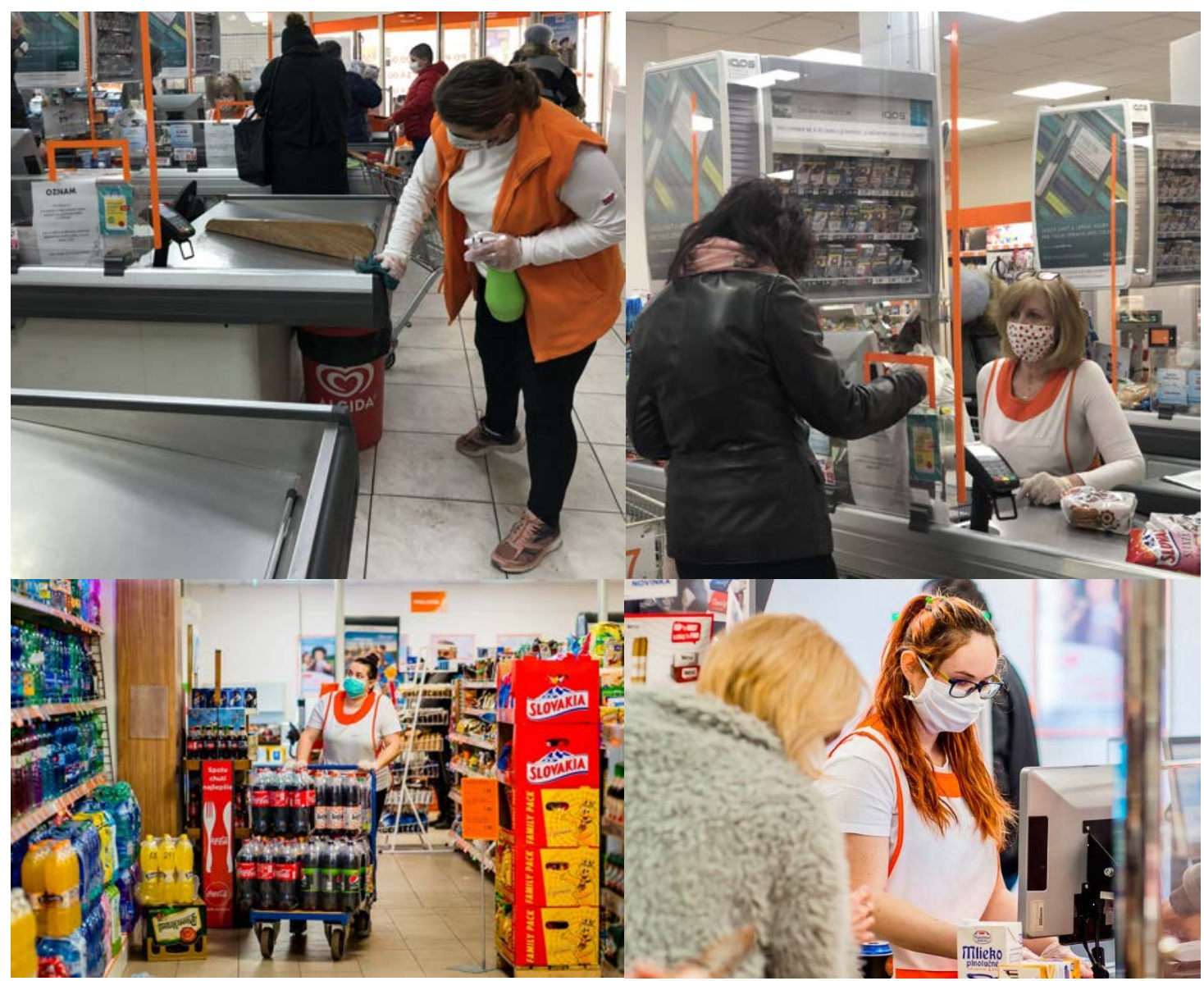

Figure 13. Hygiene measures in Coop Jednota supermarkets, Slovakia (disinfecting of the cash register, plexiglass separating the customer from the saleswoman, wearing masks) (Source: Coop Jednota, Krupina, 2020).

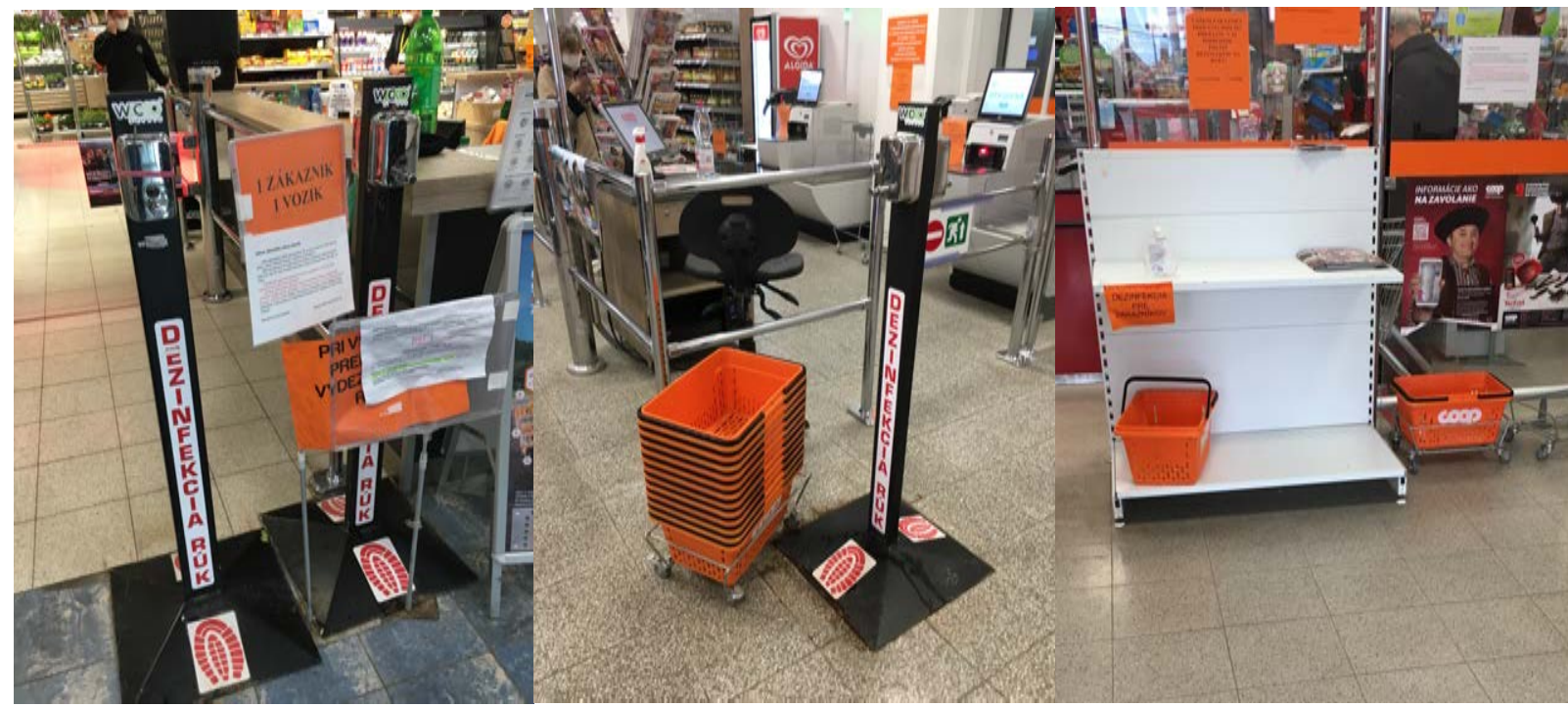

Figure 14. Stepping device for hand disinfection (Coop Jednota Tempo Supermarket, Nitra, Coop Jednota, Nitra and Coop Jednota, Nitrianske Hrnčiarovce, Slovakia).

Note: in Coop Jednota supermarkets and larger grocery stores of this retailer the hand disinfection is supervised by a security guard. In smaller grocery stores hygiene measures and hand disinfection are supervised directly by the saleswoman. 


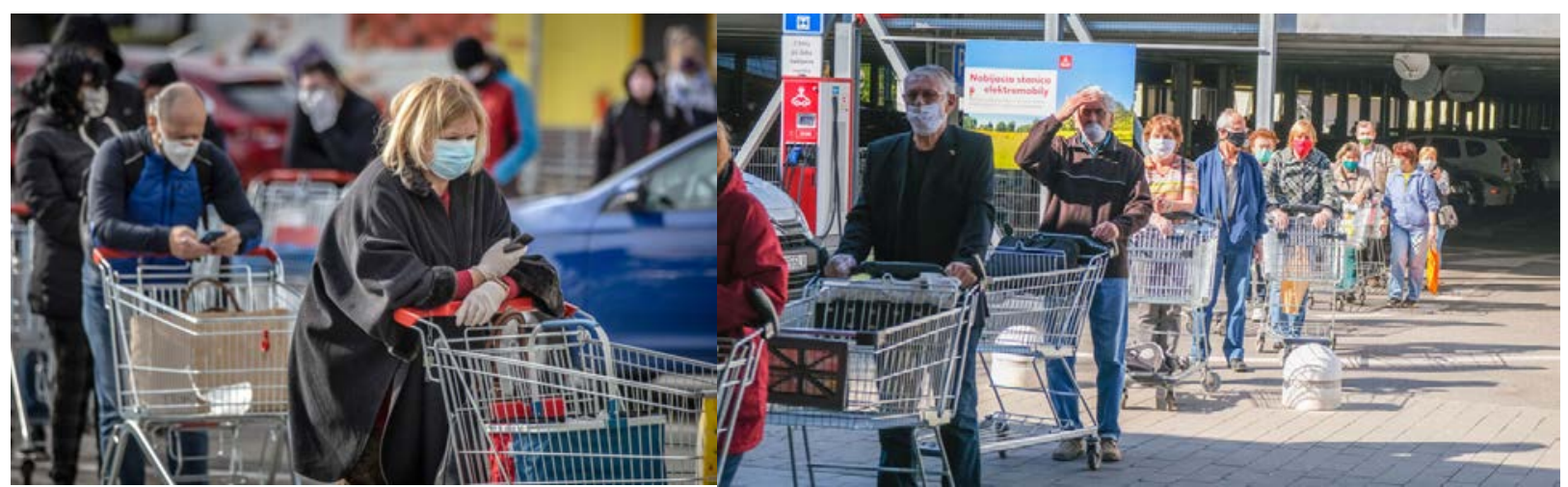

Figure 15. Customers waiting in lines in front of the stores (Source: dennikn.sk - Tomáš Benedikovič; pravda.sk Ivan Majerský).

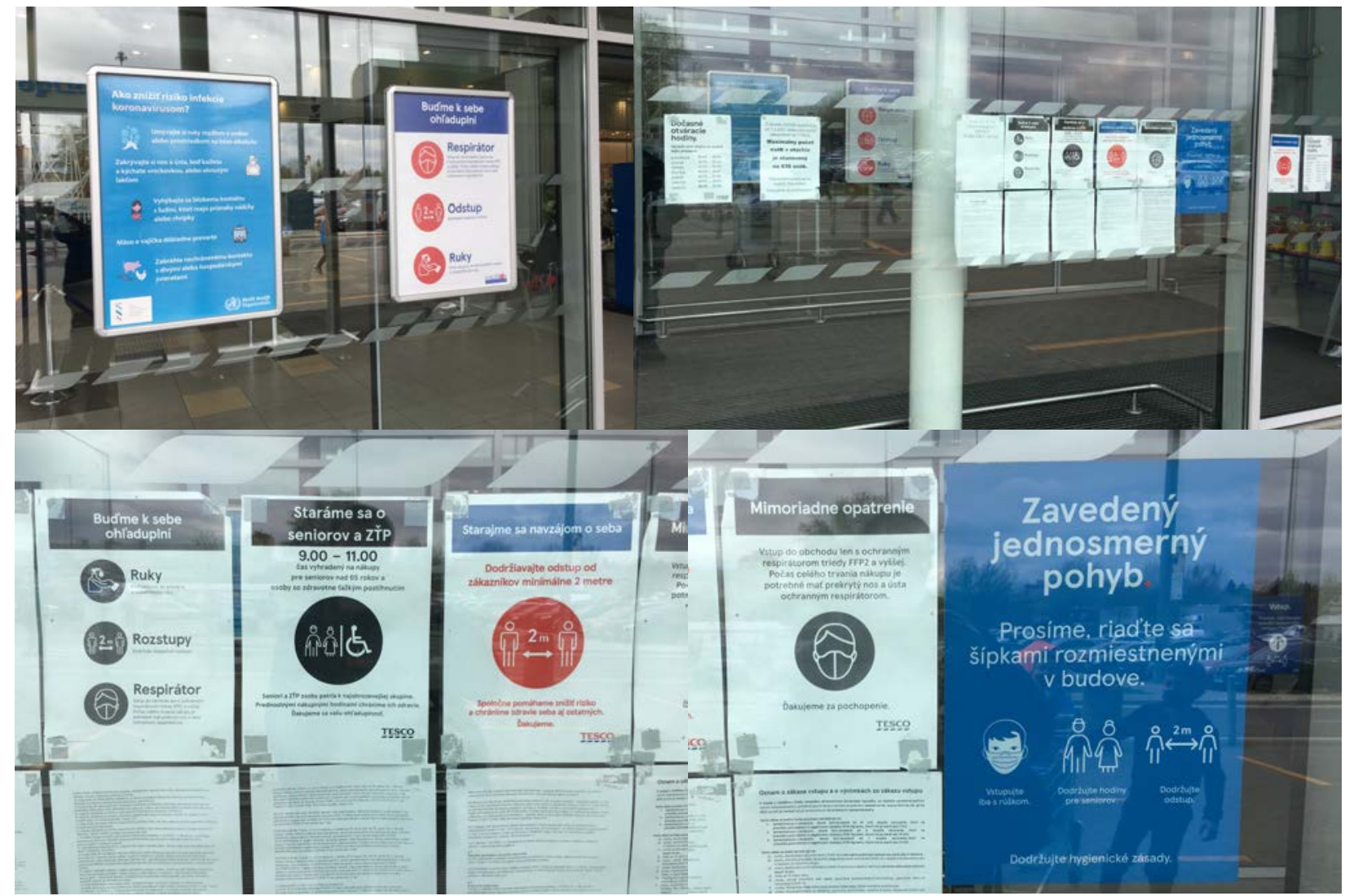

Figure 16. Information notices at the front door to the shopping center Tesco Gallery, Nitra, Slovakia.

Note: First picture: Official WHO and PHA SR poster: How to reduce the risk of coronavirus infection. Poster: Let's be careful with each other (Picograms: respirator, distance, hands with description). Second picture: Opening hours, The maximum number of people in the shopping center (Due to COVID measures, the number of customers is limited to $1 / 15 \mathrm{~m}^{2}$ from 7.2.2021. The maximum number of people in the building is set at 635 people. We apologize for any inconvenience. Thank you for understanding). There are several other notices, which are shown in detail in the figures below. Third picture: Let's be careful with each other (Pictograms: hands, distance, respirator with description). We take care of seniors and the disabled $(9.00-11.00$. Let's take care of each other (time set aside for shopping for seniors over 65 and people with severe disabilities. The elderly and the severely disabled belong to the most endangered group. We protect their health with priority shopping hours. Thank you for your consideration), Let's take care of each other (Keep a distance of at least $2 \mathrm{~m}$ from customers. Pictogram $2 \mathrm{~m}$ distance. Together, we help reduce risk and protect the health of ourselves and others. We thank you), Fourth picture: Extraordinary measure (Enter the store only with a respirator of class FFP2 and higher. During the entire duration of the purchase, it is necessary to have a covered nose and mouth with a protective respirator. Thank you for understanding.), Introduced one-way movement (Please follow the arrows located in the building. Enter only with a mask. Observe the hours for seniors. Keep your distance. Follow hygienic principles). Below these pictures are the complete wording of the decree of the PHA SR and the notice of no entry and exceptions to the entry ban. 


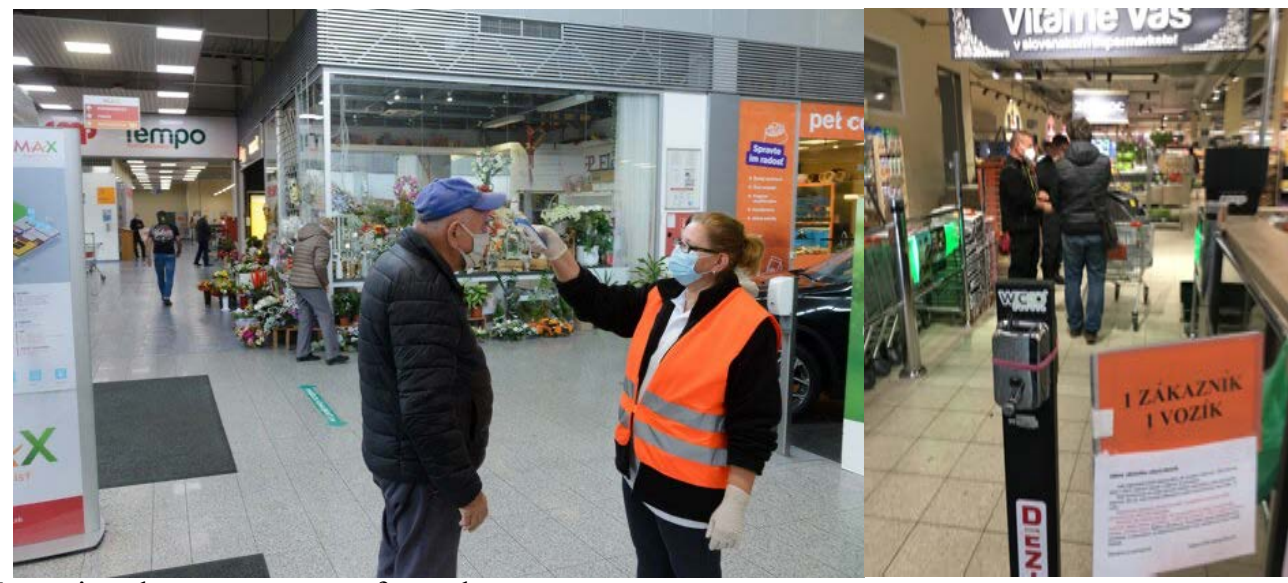

Figure 17. Measuring the temperature of people.

Note: Left: measuring the temperature of people entering the shopping center OC MAX in Nitra (Source: TASR and sme.sk). Right (measuring the temperature of people entering Tempo Jednota food supermarket, Nitra, Slovakia).

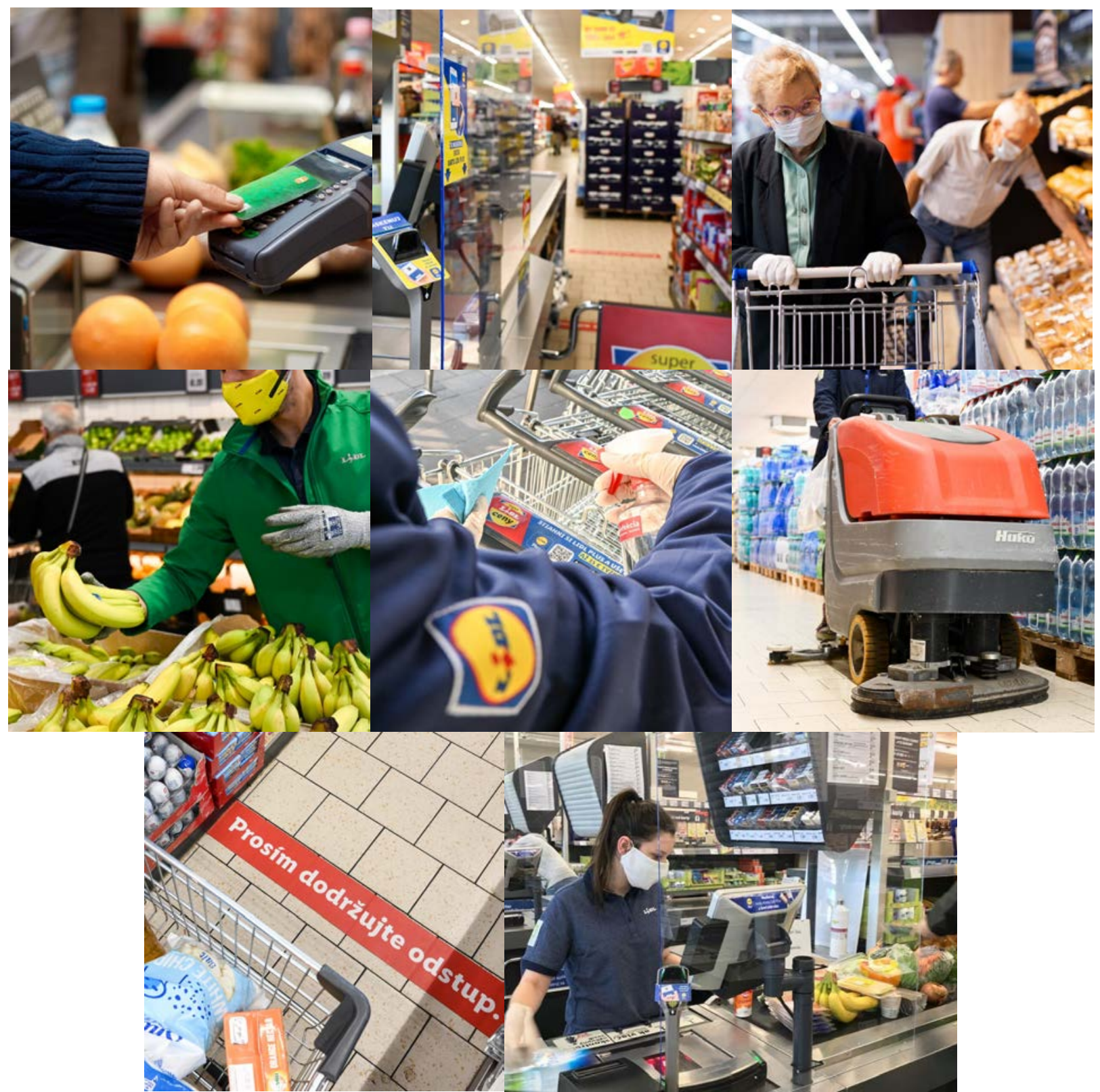

Figure 18. Hygiene measures in Lidl supermarkets, Slovakia (Source: lidl.sk).

Note: to prefer payment with card, plexiglass is separating casher from customers, opening hours for seniors, wearing FFP2 respirators by employees, shopping cart disinfection, floor disinfection, keep a distance marks on the floor, blocking of goods behind plexiglass. 


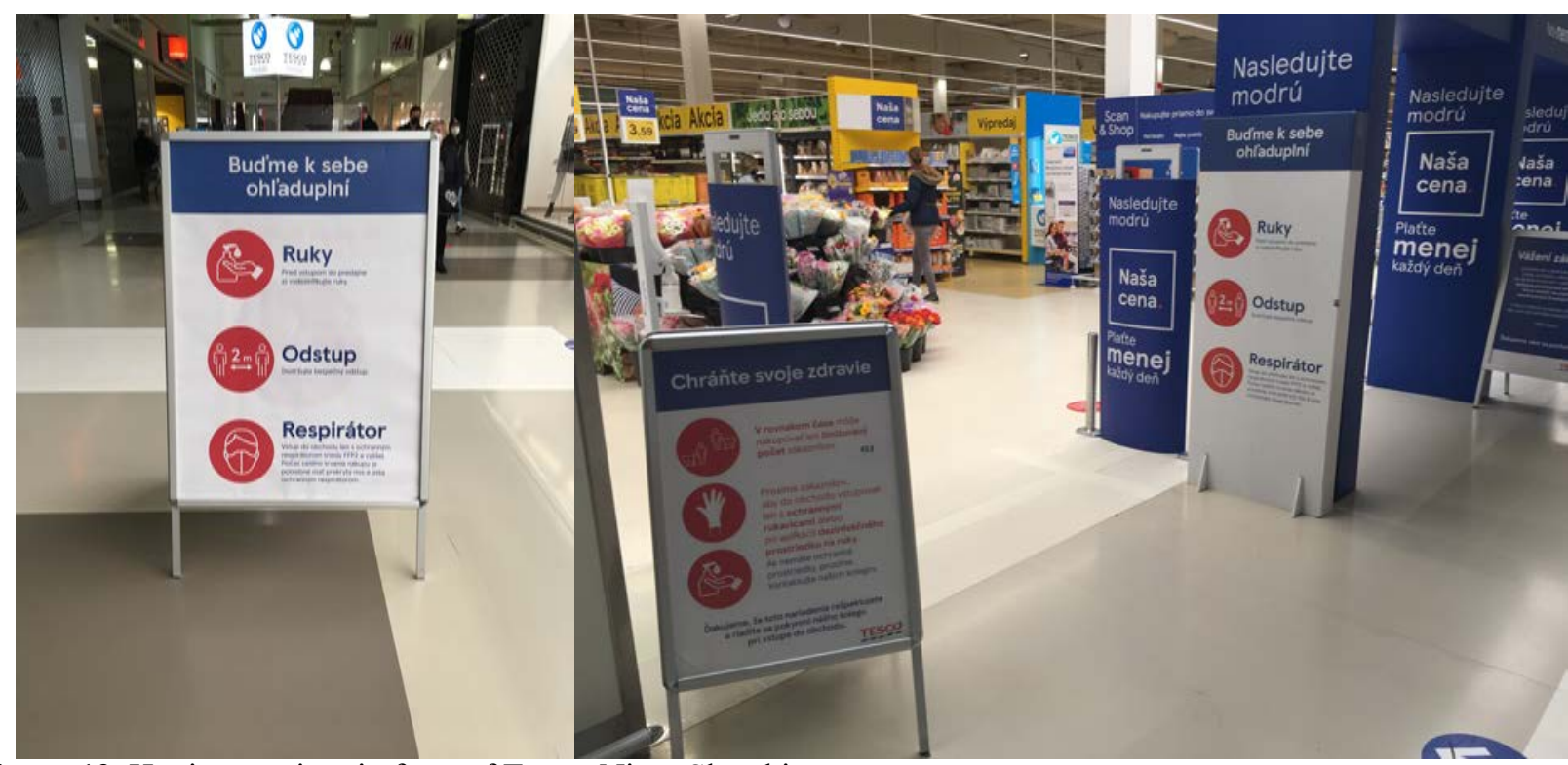

Figure 19. Hygiene notices in front of Tesco, Nitra, Slovakia.

Note: there are several large-scale posters informing consumers about hygiene requirements. Left: Let's be considerate of each other (Hand, Distane, Respirator. Disinfect your hands before entering the store. Keep a safe distance. Enter the store only with a respirator of class FFP2 and higher. It is necessary to have a covered nose and mouth with a respirator during the entire purchase). Right: Protect your health. Only a limited number of customers (453) can shop at the same time. We ask customers to enter the store only with protective gloves or after applying hand sanitizer. If you do not have protective equipment, please contact our colleagues. Thank you for respecting this regulation and following our colleague's instructions when entering the store. Blue pictogram: One-way purchase.

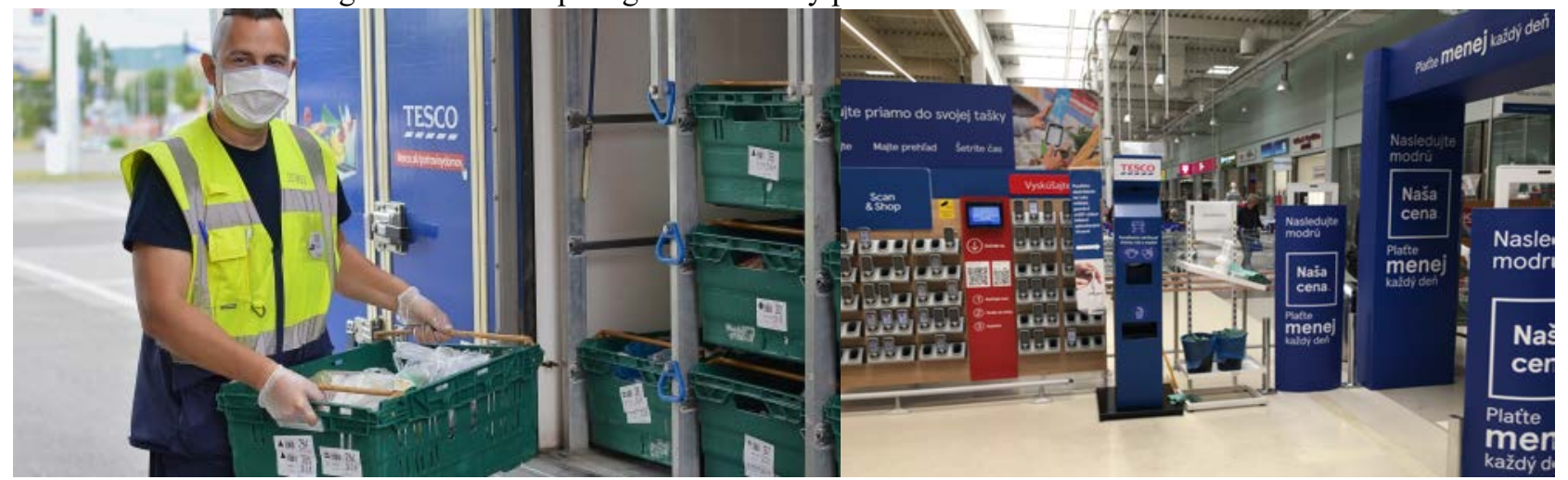

Figure 20. Home delivery service (tesco.sk).

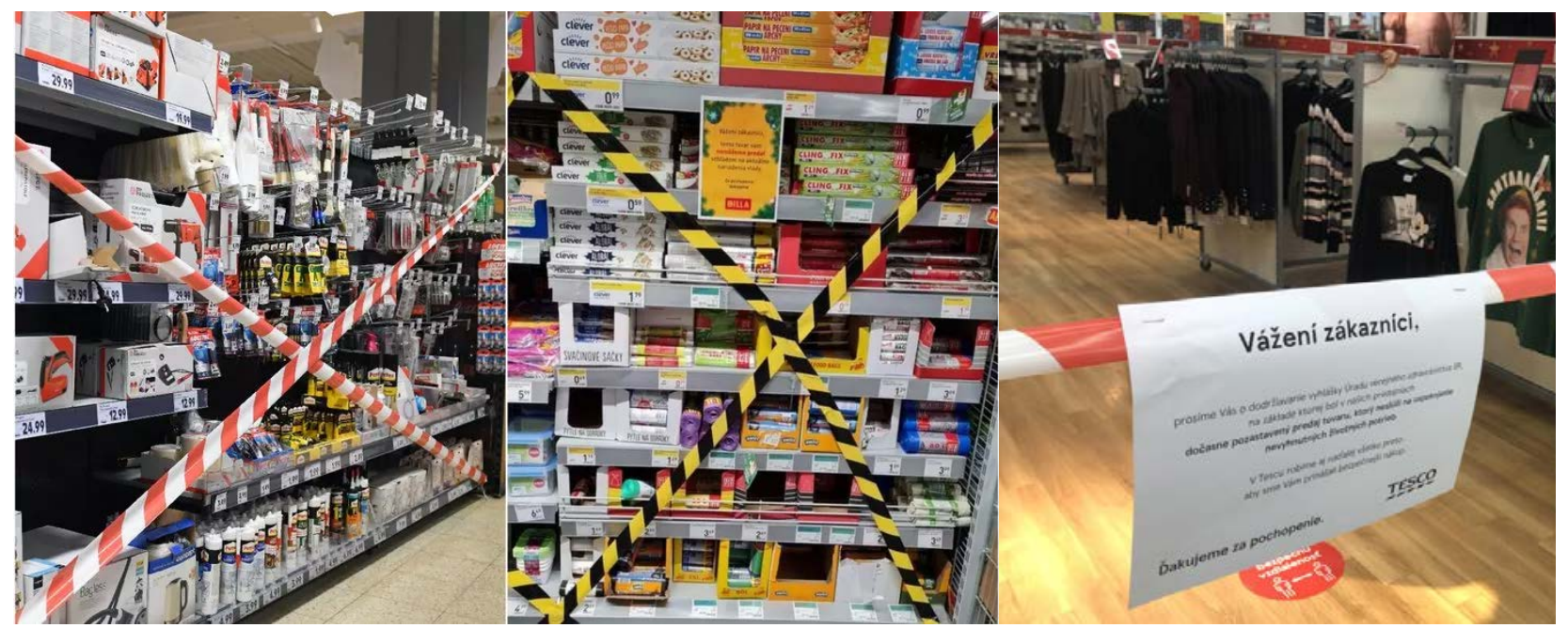

Figure 21. Restrictions on the purchase of non - foodstuffs in Slovak food supermarkets.

Note: We ask you to comply with the decree of the Public Health Authority of the Slovak Republic, based on which the sale of goods in our stores was temporarily suspended, which does not serve to satisfy the necessary necessities of life. At Tesco, we continue to do everything we can to make a safer purchase. Thank you for understanding. 


\section{Ako znižit riziko infekcie}

koronavírusom?

Umývajte si ruky mydlom a vodou alebo prostriedkom na báze alkoholu

Zakrývajte si nos a ústa, ked' kašlete a kýchate vreckovkou, alebo ohnutým laktiom

Vyhýbajte sa blizkemu kontaktu s ludimi, ktorí majú priznaky nádchy alebo chripky

Mäso a vajička dôkladne prevarte

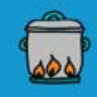

Zabráňte nechránenému kontaktu s divými alebo hospodárskymi zvieratami

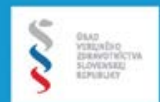

\section{Reduce your risk of coronavirus infection:}

\section{Clean hands with soap and water}

or alcohol-based hand rub

\section{Cover nose and mouth when coughing and sneezing with tissue or flexed elbow}

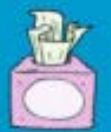

\section{Avoid close contact with anyone with cold or flu-like symptoms}

\section{Thoroughly cook meat and eggs}

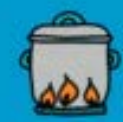

\section{Avoid unprotected contact with live} wild or farm animals

Figure 22. Official poster of the Public Health Authority of the Slovak Republic (Source: uvzsr.sk). Note: Left: Slovak version of the poster. Right: The original WHO English version of the poster.
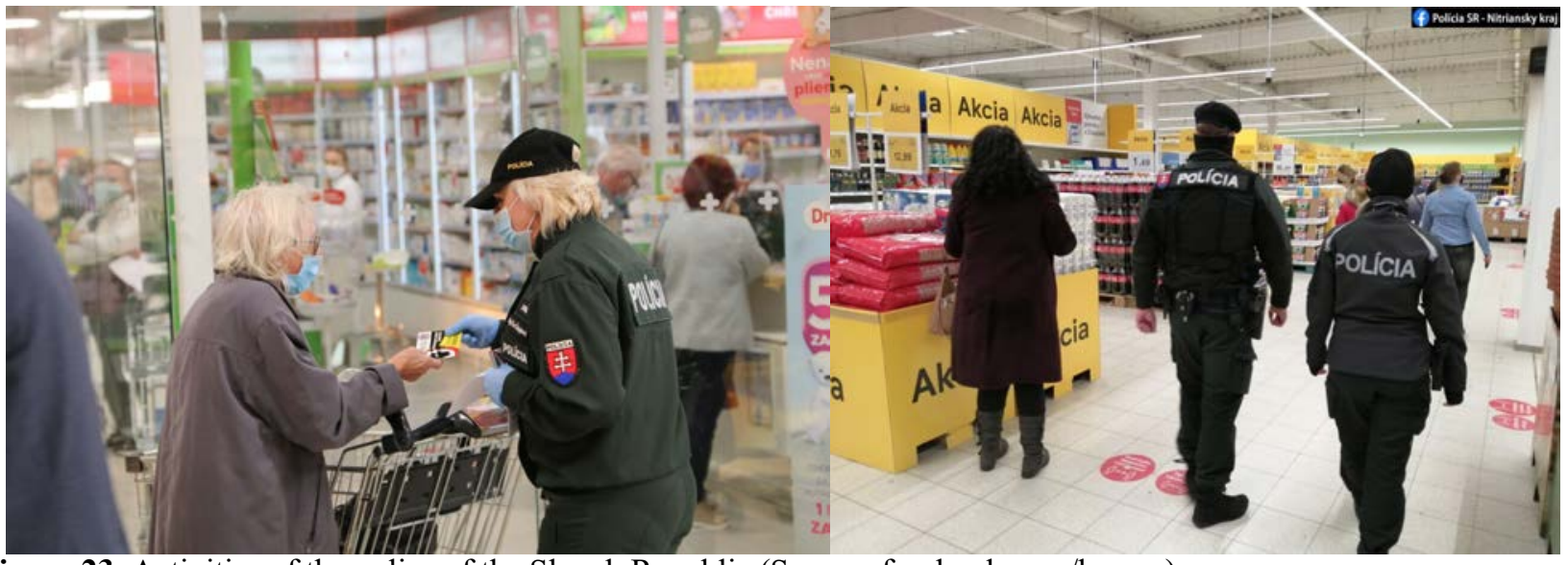

Figure 23. Activities of the police of the Slovak Republic (Source: facebook.com/krpznr).

Note: Left: Preventive campaign of the police (Fraudsters continue to abuse the situation associated with the COVID - 19 pandemic for their enrichment. They do not slowdown in their activities and will do everything to gain the trust of seniors. Under various fictional stories, they often attract lifetime savings from them. We have therefore gone to shopping malls to repeatedly warn the most vulnerable citizens of the dangers they face if they are not still vigilant in the current pandemic. We warned citizens to be careful about strangers who, for example offer temperature measurements, the sale of protective masks or disinfectant gels by phone, so that they do not give money to people they do not know and do not let strangers into their homes under any circumstances. In order to always remember our advice and warnings at home, we handed over a magnet to the addressed citizens). Right: control of compliance with anti-pandemic measures in shops by citizens. 


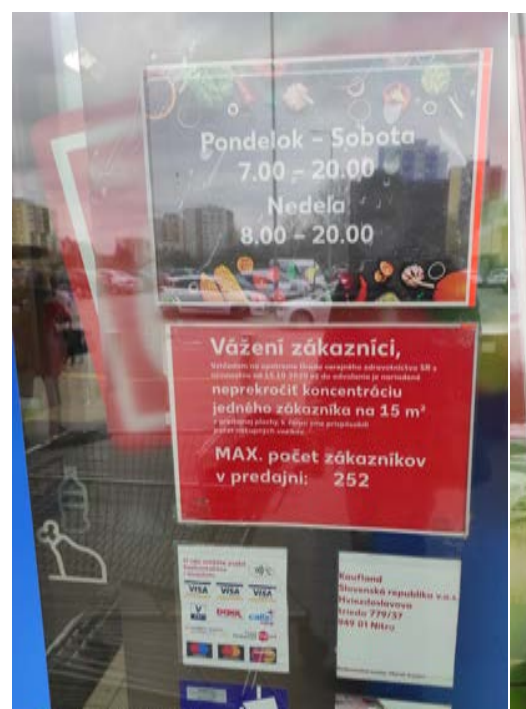

$-1$
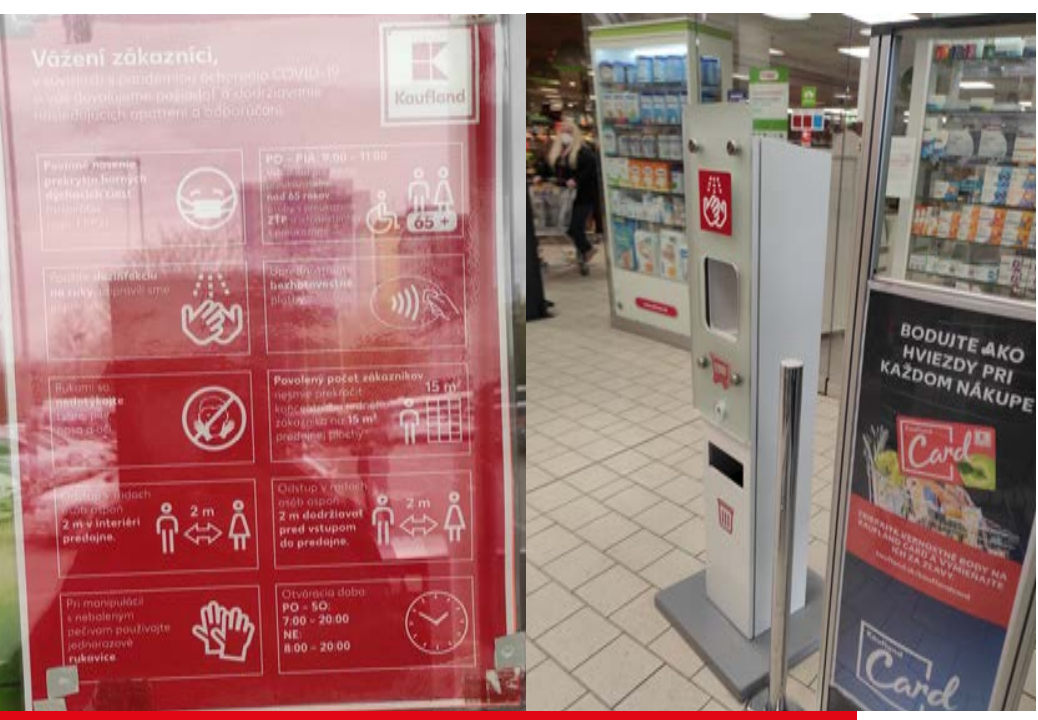

\section{Vážení zákazníci,}

v súvislosti s pandémiou ochorenia COVID-19 si vás dovolujeme požiadat o dodržiavanie nasledujūcich opatrení a odporúčaní.

$$
\begin{aligned}
& \text { Povinné nosenie prekrytia horných } \\
& \text { dýchacich ciest (napr. rúško, šál, šatka). }
\end{aligned}
$$
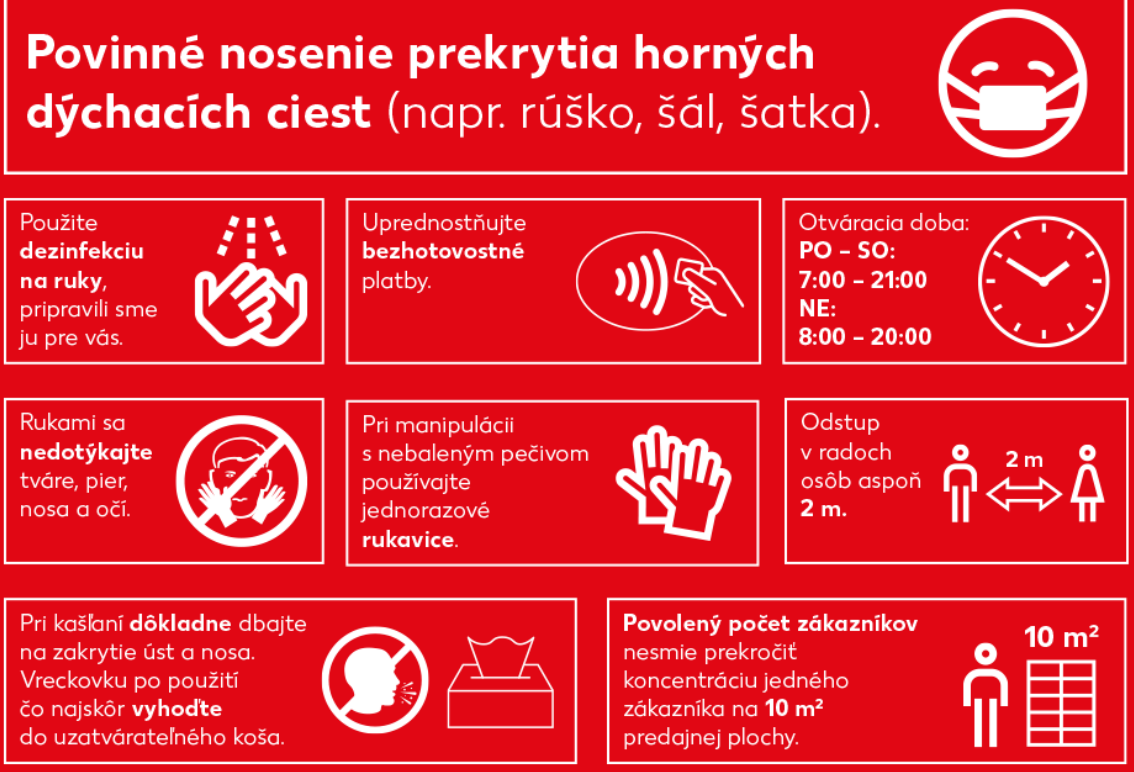

\section{D̆akujeme za pochopenie a ohladuplnost' \#spolocnetozvladneme}
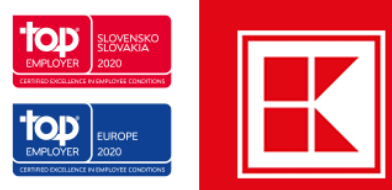

Figure 24. Hygiene measures in Kaufland, Slovakia.

Note: Left: Dear customers, concerning the measures of the Public Health Authority of the Slovak Republic with effect from 15.10 .2020 until further notice, it is ordered not to exceed the concentration of one customer per $15 \mathrm{~m}^{2}$ of sales area, to which we have adjusted the number of shopping carts. Max. number of customers in the store: 252. Middle: Dear customers, in connection with the COVID-19 pandemic, we would like to ask you to observe the following measures. Mandatory wearing of upper airway cover (respirator eg FFP2), Use hand disinfection, we have prepared it for you. Do not touch your face, lips, nose, or eyes with your hands. Distance in the rows of at least $2 \mathrm{~m}$ in the interior of the store. Use disposable gloves when handling unwrapped pastries. Opening hours: Mon-Fri: 9:00 11:00. Entry only for persons demonstrably over 65 years of age, persons with a disability card, and their assistants with a card. Prefer cashless payments. The permitted number of customers may not exceed the concentration of one customer per $15 \mathrm{~m}^{2}$ of area. Keep a distance of at least $2 \mathrm{~m}$ in the ranks before entering the store. Opening hours: Mon-Sat: 7:00 - 20:00, Sun: 8:00 - 20:00. Right: hand disinfection equipment. Bottom: Dear customers, in connection with the COVID-19 pandemic, we would like to ask you to follow the following measures and recommendations. Mandatory wearing of upper airway cover (eg drape, scarf, scarf). Use hand disinfection, we have prepared it for you. Prefer cashless payments. Opening hours: Mon-Sat: 7:00 - 21:00, Sun: 8.00 - 20:00. Do not touch your face, lips, nose, or eyes with your hands. Use disposable gloves when handling unwrapped pastries. Distance in rows of at least $2 \mathrm{~m}$. When coughing, be careful to cover your mouth and nose. Dispose of the handkerchief in a closable basket as soon as possible after use. The permitted number of customers may not exceed the concentration of one customer per $10 \mathrm{~m} 2$ of sales area. Thank you for your understanding and consideration. \#wecandoittogether. 


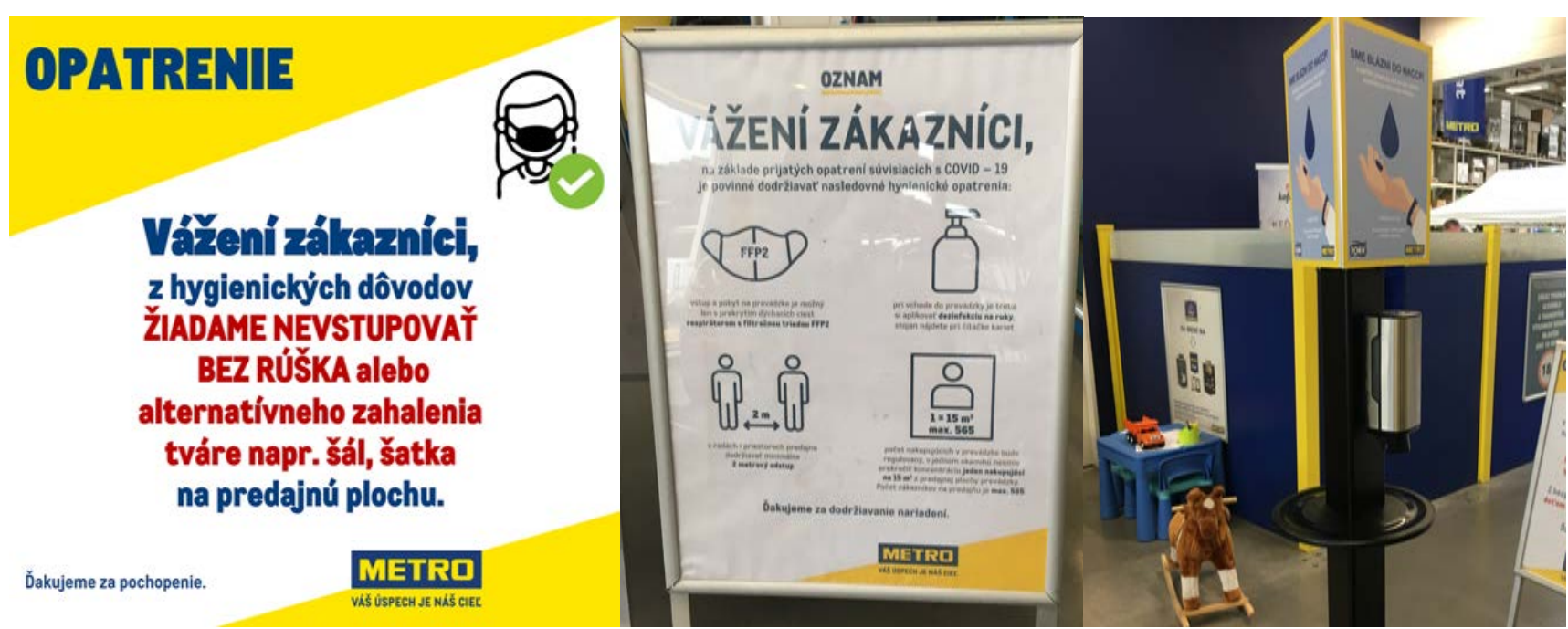

Figure 25. Notice for Metro customers (Source: metro.sk).

Note: Left: Measure. Dear customers, for hygienic reasons we ask not to enter without a mask or alternative covering, e.g. scarf, scarf on the sales area. Thank you for understanding. Subway. Your success is our goal. Middle: Notice. Dear customers, on the basis of the measures taken in connection with COVID-19, it is obligatory to observe the following hygiene measures: Entry and stay in the store is possible only with an overlay of airways in the face. Respirator with filter class FFP2. Hand disinfectant must be applied at the entrance of the store. You will find the stand next to the card reader. Keep a minimum distance of $2 \mathrm{~m}$ in the rows and areas of the store. The number of shoppers in the operation will be regulated, only one buyer per $15 \mathrm{~m} 2$ of the sales area of the store. This concentration may not exceed. The number of customers per store is max. 565. Thank you for complying with the regulations. Metro. Your success is our goal. Right: Stand with hand disinfection.
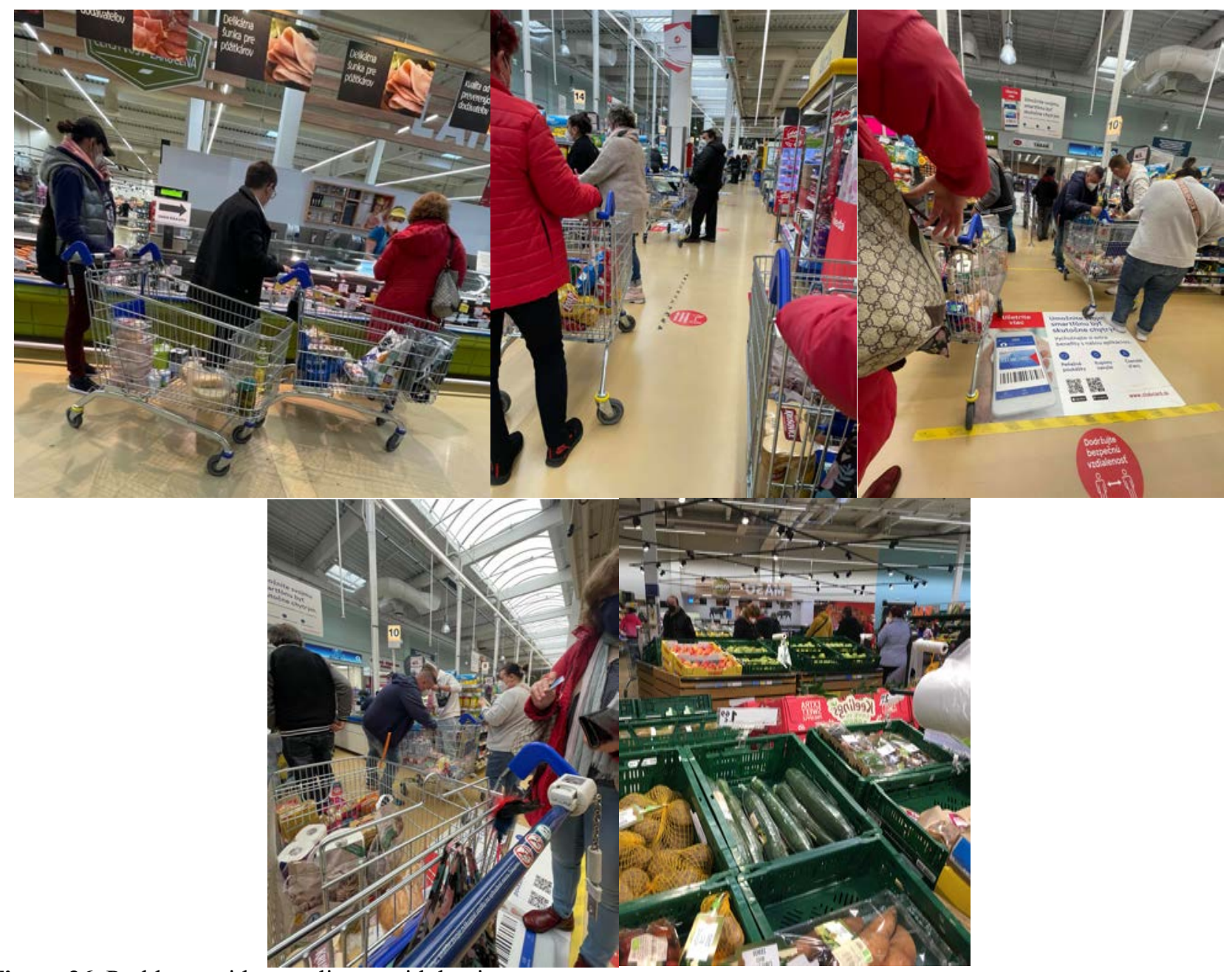

Figure 26. Problems with compliance with hygiene measures.

Note: Keeping the distance of $2 \mathrm{~m}$ is impossible during the purchase itself as well as while waiting for payment. 


\section{Diagram 3: Grocery Store}

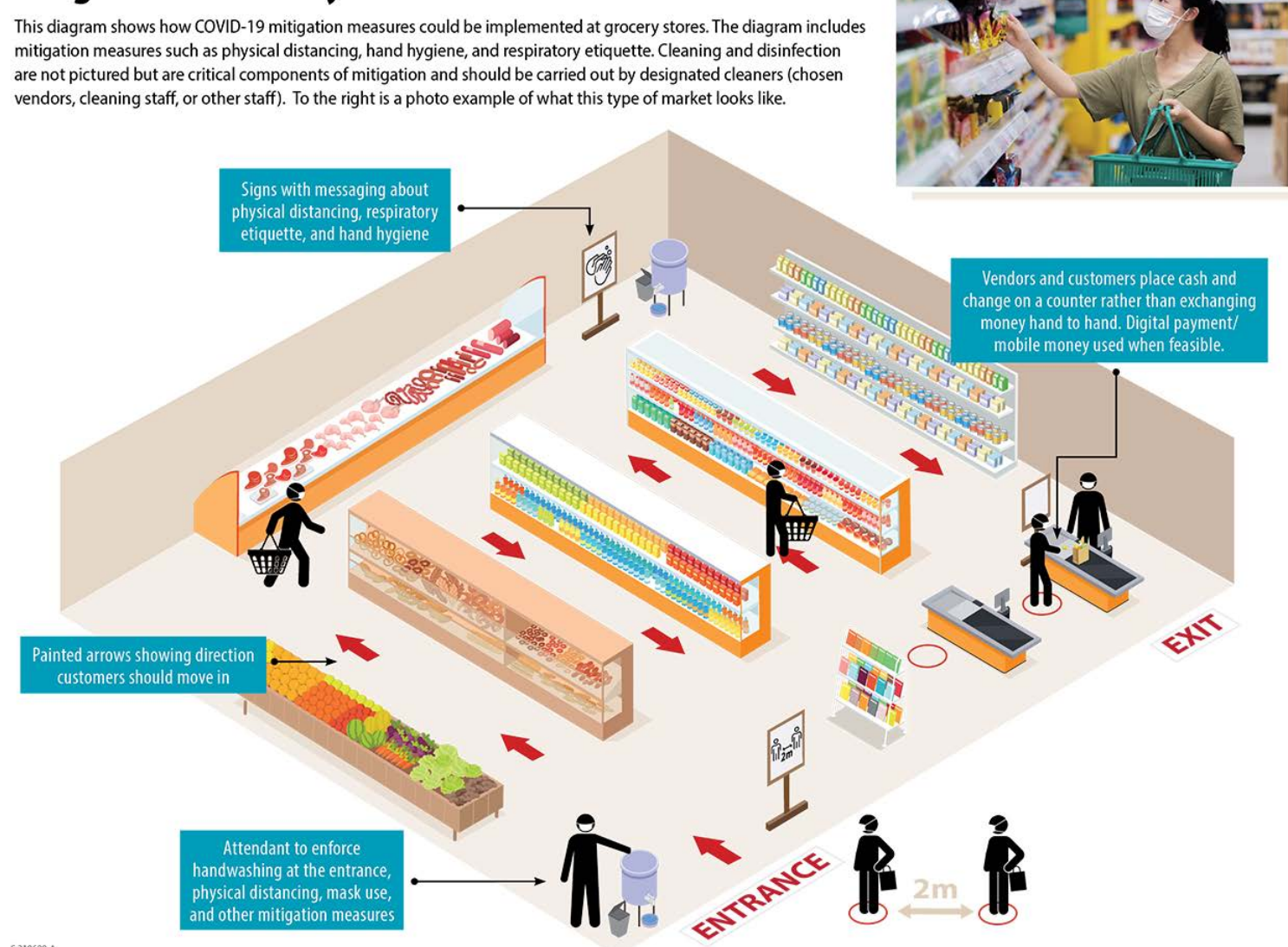

Figure 27. Examples of how the measurement should be implemented in grocery stores (CDC, 2019).

These food system workers have been pushed to the frontline of this pandemic, providing essential services that support food consumption. Food system workers are some of the most economically vulnerable populations and are at risk of further financial disparities and contraction of COVID-19 during this pandemic. As we continue to grapple with the best strategies to support the food system and mitigate concerns around the spread of COVID-19, appropriate measures must be considered to better protect and support front-line food system workers that safeguard food access for all (Parks et al., 2020).

The grocery retail industry is encountering unique challenges and opportunities during the 2019 Novel Coronavirus (COVID-19). The pandemic led to various transformations in the food retail industry, including changes in consumer perception and behavior. Although the pandemic has a situational nature, these transformations could have both temporary and long-lasting effects on reforms of the grocery retail industry (Wang, et al., 2020b). Personal consumption expenditures have been significantly affected by the economic shocks in the COVID-19 era (Dong et al., 2021). Panic buying during the novel Coronavirus (COVID-19) pandemic led to a temporary shortage of several staples and basic supplies in grocery stores, thus limiting the public's access to basic needs and exacerbating stress and anxiety (Kassas and Nayga, 2021). We agree, many people have restricted shopping as such and are buying food in the nearest groceries, as ordered by the Public Health Authority of the Slovak Republic. However, we have also noticed that people are moving to the shopping center by car, even though most shops have to be closed. They justify this move by the need to buy their favorite foods, including pharmacy medicines and pet food at a specialist pet store.

As a result of the COVID-19 pandemic, the adoption of healthier food habits varied significantly with gender, age, and household income. There is a need to raise awareness among people on how to shop safely in grocery stores and that good hygiene practices should be followed in grocery stores to mitigate the risk of infection to consumers (Shamim, Ahmad and Alam, 2021).

During the COVID-19 crisis food habits have changed among the population as food consumption is now carried out totally at home, and visits to groceries or food centers have decreased considerably (Sinisterra-Loaiza, 2020), and in some countries, such as the Slovak Republic, there has been a complete decline in the hotel and catering sector. COVID-19 brought a high degree of disruption for society, firms, and consumers. Retail, grocery, and food services have been particularly affected as they were expected to maintain their operations while mitigating marketplace risks (Aboelenien, Arsel and Cho, 2021).

In some countries like Slovakia where the restriction adopted by the authorities were too strict, many small food establishments went bankrupt. Supermarkets and grocery stores continue to operate, albeit in a restricted mode, supplying people with food and showing sales, and possibly making a profit.

COVID-19 continues to impose a series of unique challenges on the food retail and foodservice sectors in Canada. In May 2020, the expectation was that the public health crisis shutdowns of the restaurant sector would be 
temporary. Grocery stores have solidified their changed realities through an increased focus on multiple channel retailing rather than a complete choice between either bricks and mortar or online.

Increased costs, resulting from the pandemic, are continuing to filter through the food system and we have a growing problem with food security for some Canadians given that employment in January 2021 was found to be at its lowest level since August 2020. Unemployment moves directly with lockdowns that are varied across the country (Goddard, 2021). There is a sharp growth in demand for food deliveries and online grocery (Gabriel, Darwish and Hassanien, 2021).

We agree, many respondents in our questionnaire survey stated that they use the home delivery service. Food delivery directly to the home in Slovakia was offered mainly by two retailers: Metro Cash \& Carry and by Tesco.

Some municipalities ensured the purchase of food for the elderly and brought it directly to their house.

During the coronavirus disease-2019 pandemic, online grocery shopping experienced a never seen popularity in many countries. Amazon seems to follow its low-price strategy also in the grocery sector, even in times of high demand. However, during the lockdown phase, there were more price increases for certain highly demanded product groups such as frozen and prepared foods (Hillen, 2021).

Online grocery shopping is a way of purchasing food products using a web-based shopping service. The current COVID-19 pandemic is determining a rethinking of purchase choice elements and consumers' behavior. The results of this work highlight that people having familiarity with buying food online, that have a higher educational level and consider food online channels easy to use, appear more satisfied with the food online shopping experience. These findings can be crucial for the future green global challenges as online shopping may help to reach competitive advantages for company sustainability (Alaimo, Fiore and Galati, 2020). Online shopping for food products is quickly accelerating worldwide, particularly following the impact of the COVID-19 pandemic. Most e-grocers are multichannel supermarkets that have developed online channels. Variables defining retailer brand equity, i.e., retailer awareness, retailer associations, retailer perceived quality, and retailer loyalty contribute, together with perceived usefulness, to explain intentions to shop online at multichannel supermarkets (Bandenhop and Frasquet, 2021).

\section{CONCLUSION}

Hygiene measures against COVID-19 applied in food stores in the Slovak Republic are adequate and sufficient. It is very important to ensure that they are enforceable in practice. As commercial establishments are private, traders must ensure compliance with them themselves. The Public Health Authority of the Slovak Republic supervises their observance. The activities of the city police and the state police are necessary to ensure compliance with the measures in public places.

The most important hygiene measures in supermarkets, retail food stores, and grocery shops during the COVID-19 pandemic in Slovakia were: to wear masks and later wear a respirator of FFP2 class in public areas outside and inside, gloves on hands, or disinfection of customers' hands before entering the store, observance of $2 \mathrm{~m}$ distance of people standing in a row at the cash registers, maximum capacity one person per $25 \mathrm{~m}^{2}$ of sales area and later one person per $15 \mathrm{~m}^{2}$ of sales area, a limited number of shopping baskets and trolleys, specific purchase time only for seniors from 9:00 to 11:00 AM, to perform regular air ventilation of the premises and to have as many cash registers as possible so as not to create long lines of customers, regular disinfection of the shopping baskets and trolleys, regular disinfection of all surface in direct contact with customers like cash register belts, handles in refrigerators and freezers, pastry tongs, etc. In shopping centers, entry was prohibited for people with a body temperature higher than $37^{\circ} \mathrm{C}$. Shopping time allowed only to 8:00 PM.

During the peak of the pandemic, there was a restriction for persons to shop food only in the nearest retail/grocery or similar place from the place of residence to the extent necessary to procure the essential needs of life.

Most consumers think that the hygiene measures implemented in stores are sufficient. Almost one-third of the respondents believe that these measures are not sufficient or they are not properly performed by the seller.

It is very difficult to meet the measure of $2 \mathrm{~m}$ distance between buyers. The benevolent attitude of the population towards the measures taken and the indiscipline is a problem that the authorities must take into account when propose and adopt hygiene measures in legislation. The individual measures should be applied from a practical point of view, otherwise, they cause problems for all parties involved, official control bodies, sellers, and customers.

The grocery seller wants to sell groceries and not argue with the customer. It is annoying for the seller to constantly verbally warn customers to follow the specific COVID-19 hygiene measures. Such warnings may result in the loss of the customer and profit. On the other hand, in times of emergency, traders may be pleased that the government and public health authority have allowed them to operate their businesses and should therefore provide the measures required by the state. However, these measures must be based on sound reason. If the state wants to ensure food security and the necessary necessities of life in times of emergency measures for citizens, the help of the private sector and the participation of food retailers is necessary.

The information campaign on hygiene measures must be simple, clear and clearly communicated to citizens. We recommend unifying the visual appearance of pictograms, which should be used uniformly throughout the country and published in the legislation as mandatory. Ensure their contrast and good resolution, use blue color for notification or recommendation, and red color for prohibition. Uniform pictograms could then be incorporated by retailers into their corporate graphics.

\section{REFERENCES}

Abdi, H., Williams, L. J. 2010. Principal Component Analysis. WIREs Comp. Stat., vol. 2, p. 433-459. https://doi.org/10.1002/wics.101

Aboelenien, A., Arsel, Z., Cho, C. H. 2021. Passing the buck versus sharing responsibility: The roles of government, firms, and consumers in marketplace risks during COVID-19. Journal of the Association for Consumer Research, vol. 6, no. 1, p. 149-158. https://doi.org/10.1086/711733 
Alaimo, L. S., Fiore, M., Galati, A. 2020. How the COVID19 pandemic is changing online food shopping human behavior in Italy. Sustainability (Switzerland), vol. 12, no. 22, article number 9594, p. 1-18. https://doi.org/10.3390/su12229594

Bandenhop, A., Frasquet, M. 2021. Online Grocery Shopping at Multichannel Supermarkets: The Impact of Retailer Brand Equity. Journal of Food Products Marketing, p. 89-104. https://doi.org/10.1080/10454446.2021.1894296

Butt, Y., Kurdowska, A., Allen, T. C. 2016. Acute lung injury: a clinical and molecular review. Arch. Pathol. Lab. Med., vol. 140, no. 4, p. 345-350. https://doi.org/10.5858/arpa.2015-0519-RA

CDC, 2019. Markets: Operational considerations for COVID-19 mitigation measures in global low resource settings. Centers for Disease Control and Prevention, USA. Available at: https://www.cdc.gov/coronavirus/2019ncov/global-COVID-19/markets.htm

CDC, 2020a. Coronavirus (COVID-19). Centers for Disease Control and Prevention, USA. Available at: https://www.cdc.gov/coronavirus/2019-ncov/index.html

CDC, 2020b. Coronavirus consumer trends: Consumer electronics, pet supplies, and more. Centers for Disease Control and Prevention, USA. Available at: https://www.criteo.com/insights/coronavirus-consumertrends/

Chan, J. F., Yuan, S., Kok, K. H., To, K. K. W., Chu, H., Yang, J., Xing, F., Liu, J., Yip, C. CH. Y., Poon, R. W. S., Tsoi, H.W., Lo, S. K. F., Chan, K. H., Poon, V. K. M., Chan, W. M., Ip, J. D., Cai, J. P., Cheng, V. CH. CH., Chen, H. K. M., Hui, CH., Yuen, K. Y. 2020. A familial cluster of pneumonia associated with the 2019 novel coronavirus indicating personto-person transmission: a study of a family cluster. Lancet, vol. 395 , p. 514-523. https://doi.org/10.1016/S0140$\underline{6736(20) 30154-9}$

Dong, D., Gozgor, G., Lu, Z., Yan, C. 2021. Personal consumption in the United States during the COVID-19 crisis. Applied Economics, vol. 53, no. 11, p. 1311-1316. https://doi.org/10.1080/00036846.2020.1828808

EU, 2002. Regulation (EC) No 178/2002 of the European Parliament and of the Council of 28 January 2002 laying down the general principles and requirements of food law, establishing the European Food Safety Authority, and laying down procedures in matters of food safety. OJ L 31, 1.2.2002, p. $1-24$.

EU, 2004. Regulation (EC) No 852/2004 of the European Parliament and of the Council of 29 April 2004 on the hygiene of foodstuffs. OJ L 139, 30.4.2004, p. 1-54.

Ferguson, N. M., Laydon, D., Nedjati-Gilani, G., Imai, N., Ainslie, K., Baguelin, M., Bhatia, S., Boonyasiri, A., Cucunubá Z., Cuomo-Dannenburg, G., Dighe, A., Dorigatti, I., Fu, H., Gaythorpe, K., Green,W., Hamlet, A., Hinsley, W., Okell, L. C., van Elsland, S., Thompson, H., Verity, R., Volz, E., Wang, H., Wang, Y., Walker, P. G. T., Walters, C., Winskill, P., Whittaker, CH., Donnelly, CH. A., Riley, S., Ghani, A. C. 2020. Report 9: Impact of non-pharmaceutical interventions (NPIs) to reduce COVID-19 Mortality and Healthcare Demand. Imperial CollegeCOVID-19 Response Team, p. 1-20. https://doi.org/10.25561/77482

Gabriel, A. J., Darwish, A., Hassanien, A. E. 2021. Cyber security in the age of COVID-19. Studies in Systems, Decision and Control, vol. 322, p. 275-295. https://doi.org/10.1007/9783-030-63307-3 18

Goddard, E. 2021. The impact of COVID-19 on food retail and food service in Canada: A second assessment. Canadian Journal of Agricultural Economics, (article in press). https://doi.org/10.1111/cjag.12282
Hassen, T. B., El Bilali, A., Allahyari, M. S., 2020. Impact of COVID-19 on Food Behavior and Consumption in Qatar. Sustainability, vol. 12, no. 17, article no. 6973, p. 1-18. https://doi.org/10.3390/su12176973

Hillen, J. 2021. Online food prices during the COVID-19 pandemic. Agribusiness, vol. 37, no. 1, p. 91-107. https://doi.org/10.1002/agr.21673

Huang, C., Wang, Y., Li, X., Ren, L., Zhao, J., Hu, Y., Zhang, L., Fan, G., Xu, J., Gu, X., Cheng, Z., Yu, T., Xia, J., Wei, Y., Wu, W., Xie, X., Yin, W., Li, H., Liu, M., Xiao, Y., Gao, H., Guo, L., Xie, J., Wang, G., Jiang, R., Gao, Z., Jin, Q., Wang, J., Cao, B. 2020. Clinical features of patients infected with 2019 novel coronavirus in Wuhan, China. Lancet, vol. 395 , p. 497-506. https://doi.org/10.1016/S0140$\underline{6736(20) 30183-5}$

Huppert, L. A., Matthay, M. A., Ware, L. B. 2019. Pathogenesis of acute respiratory distress syndrome. Semin. Respir. Crit. Care Med., vol. 40, no. 1, p. 31-39. https://doi.org/10.1055/s-0039-1683996

Jain, R., Puri, M., Jain, B., 2021. Disaster Management Using Recent Technologies During COVID-19. Studies in Systems, Decision and Control, vol. 324, p. 241-256. https://doi.org/10.1007/978-3-030-60039-6 12

Jribi, S., Ben Ismail, H., Doggui, D., Debbabi, H. 2020. COVID-19 virus outbreak lockdown: What impacts on household food wastage? Environment, Development and Sustainability, vol. 22, p. 3939-3955. https://doi.org/10.1007/s10668-020-00740-y

Kassas, B., Nayga, R. M. 2021. Understanding the importance and timing of panic buying among U.S. Households during the COVID-19 pandemic. Food Quality and Preference, vol. 93, article no. 104240, https://doi.org/10.1016/j.foodqual.2021.104240

Li, Q., Guan, X. H., Wu, P., Wang, X., Zhou, L., Tong, Y., Ren, R., Leung, K. S. M., Lau, E. H. Y., Wong, J. Y., Xing, X., Xiang, N., Wu, Y., Li, CH., Chen, Q., Li, D., Liu, T., Zhao, J., Liu, M., Tu, W., Chen, CH., Jin, L., Yang, R., Wang, Q., Zhou, S., Wang, R., Liu, H., Luo, Y., Liu, Y., Shao, Ge., Li, H., Tao, Z., Yang, Y., Deng, Z., Liu, B., Ma, Z., Zhang, Y., Shi, G., Lam, T. T. Y., Wu, J. T., Gao, G. F., Cowling, B. J., Yang, Bo., Leung, G. M., Feng, Z. 2020. Early transmission dynamics in Wuhan, China, of novel coronavirusinfected pneumonia. N. Engl. J. Med., vol. 382, p. 1199-1207. https://doi.org/10.1056/NEJMoa2001316

MDSR, 2020. Operation Joint Responsibility. Ministry of defence of the Slovak Republic. Available at: https://www.somzodopvedny.sk (In Slovak)

MH SR, 2021. Covid automat. Alert system for epidemic monitoring and admission anti-epidemic measures depending on the intensity of SARSCoV-2 (COVID-19). Ministry of Health of the Slovak Republic. Available at: https://www.health.gov.sk/Zdroje?/Sources/tlacove_spravy/C OVID-19/Covid-automat.pdf (In Slovak)

MIRDI SR, 2021a. Development of the epidemic situation in Slovakia 6.3. 2020. - 18.4.2021: Available at: https://korona.gov.sk/ (In Slovak)

MIRDI SR, 2021b. Actual regional Covid Automat. Slovakia 19.4.2021 - 25.4.2021. Available at: https://korona.gov.sk/

Mokra, D., Kosutova, P. 2015. Biomarkers in acute lung injury. Respir. Physiol. Neurobiol., vol. 209, p. 52-58. https://doi.org/10.1016/j.resp.2014.10.006

MPRV SR, 2012a. Decree No. 423 of the Ministry of Agriculture and Rural Development of the Slovak Republic of 14 December 2012 on the meat of animals for slaughter. Available at: https://www.slov-lex.sk/pravnepredpisy/SK/ZZ/2012/423/20130101 (In Slovak) 
MPRV SR, 2012b. Decree No. 99 of the Ministry of Agriculture and Rural Development of the Slovak Republic of 9 March 2012 on deep-frozen foods. Available at: https://www.slov-lex.sk/pravne-predpisy/SK/ZZ/2012/99/2 0170101 (In Slovak)

MPRV SR, 2014. Decree No. 24 of the Ministry of Agriculture and Rural Development of the Slovak Republic of 23 January 2014 on bakery products, confectionery, and pasta. Available at: https://www.slov-lex.sk/pravnepredpisy/SK/ZZ/2014/24/ (In Slovak)

NR SR, 1995. The law of the national council of the Slovak Republic of 27 June 1995 on food. Available at: https://www.slov-lex.sk/pravne-

predpisy/SK/ZZ/1995/152/19970101.html (In Slovak)

Paolone, S. 2017. Extracorporeal membrane oxygenation (ECMO) for lung injury in severe acute respiratory distress syndrome (ARDS): review of the literature. Clin. Nurs. Res., vol. 26, no. 6, p. 747-762. https://doi.org/10.1177/1054773816677808

Parks, C. A., Nugent, N. B., Fleischhacker, S. E., Yaroch, A. L., 2020. Food system workers are the unexpected but under protected COVID heroes. Journal of Nutrition, vol. 150, no. 8, p. 2006-2008. https://doi.org/10.1093/jn/nxaa173

PHA SR, 2020a. The measure of the Public Health Authority of the Slovak Republic, no. OLP / 2733/2020, 2020. Available at:

https://www.uvzsr.sk/docs/info/covid19/Opatrenie_UVZSR_z akaz_prevadzok_v_nedelu_sanitarny_den_24032020.pdf (In Slovak)

PHA SR, 2020b. The measure of the Public Health Authority of the Slovak Republic, no. OLP / 2777/2020, 2020. Available at:

https:/www.uvzsr.sk/docs/info/covid19/Opatrenie_UVZ_SR $\%$ 20final_uzatvorenie_prevadzok_rezimove_opatrenia_HH SR_29032020.pdf (In Slovak)

PHA SR, 2020c. The measure of the Public Health Authority of the Slovak Republic, no. OLP / 3461/2020, 2020. Available at:

https://www.uvzsr.sk/docs/info/covid19/22_04_2020_otvoren ie_prevadzok_rezimove_opatrenia_HH_SR.pdf (In Slovak)

PHA SR, 2020d. The measure of the Public Health Authority of the Slovak Republic, no. OLP / 3795/2020, 2020. Available at: https://www.ruvztv.sk/wpcontent/pdf_downloads/covid_19/opatrenie_uvzsr_prevadzky 2_faza_05_05_2020.pdf (In Slovak)

PHA SR, $\overline{2} 020 \mathrm{e}$. The measure of the Public Health Authority of the Slovak Republic, no. OLP / 4083/2020, 2020. Available at:

https://www.uvzsr.sk/docs/info/covid19/19_05_2020_navrh opatrenie_UVZ_SR_prevadzky_3 faza_01.pdf(In Slovak)

PHA SR, 2020f. The measure of the Public Health Authority of the Slovak Republic, no. OLP / 4362/2020, 2020. Available at:

https://www.uvzsr.sk/docs/info/covid19/26_05_zmena_opatre nia_prevadzky_vynimky.pdf (In Slovak)

PHA SR, 2020g. The measure of the Public Health Authority of the Slovak Republic, no. OLP / 4592/2020, 2020. Available at:

https://www.uvzsr.sk/docs/info/covid19/final_opatrenie_prev adzky_4_faza_02_06.pdf(In Slovak)

PHA SR, 2020h. The measure of the Public Health Authority of the Slovak Republic, no. OLP / 5091/2020, 2020. Available at: https://www.ruvztv.sk/wpcontent/pdf_downloads/covid_19/19_06_final_opatrenia_pre vadzky_a_hp.pdf (In Slovak)
PHA SR, 2020i. The measure of the Public Health Authority of the Slovak Republic, no. OLP / 7694/2020, 2020. Available at: https://www.ruvzpp.sk/opatrenie-uvz-sr-prevadzky-ahromadne-podujatia-olp-7694-2020/ (In Slovak)

PHA SR, 2020j. The measure of the Public Health Authority of the Slovak Republic, no. OLP / 8326/2020, 2020. Available at:

https://www.uvzsr.sk/docs/info/covid19/final_opatrenie_prev adzky_a_HP_15_10.pdf (In Slovak)

PHA SR, 2020k. Decree of PHA SR no. 45: Decree of the Public Health Authority of the Slovak Republic, which prescribes measures in the event of a threat to public health to restrict operations and mass events. Journal of the Government of the Slovak Republic, vol. 30, no. 26, 17. December 2020. Available

https://www.uvzsr.sk/docs/info/ut/ciastka_26_2020.pdf (In Slovak)

PHA SR, 2021a. Decree of the Regional Office of the Public Health Authority of the Slovak Republic with its seat in Rimavska Sobota, which prescribes measures in the event of a threat to public health for the city of Tisovec. Journal of the Government of the Slovak Republic, vol. 31, no. 32, 22. February 2021. Available at: https://www.minv.sk/swift_data/source/verejna_sprava/vestni k_vlady_sr_rok_2021/ciastka_32_2021.pdf

PHA SR, $202 \overline{1}$ b. Decree of $\bar{R} O \bar{P} H A$ SR TT no. 37 Decree of the Regional Office of Public Health Authority with its seat in Trnava, which prescribes measures in the event of a threat to public health for the districts of Trnava, Hlohovec and Pieśt'any. Journal of the Government of the Slovak Republic, vol. 31, no. 16, 2. February 2021. Available at: https://www.uvzsr.sk/docs/info/ut/ciastka_16_2021.pdf (In Slovak)

PHA SR, 2021c. Decree of PHA SR, No. 98, 2021 Decree of the Public Health Authority of the Slovak Republic, which prescribes measures in the event of a threat to public health to restrict operations and mass events. Journal of the Government of the Slovak Republic, vol. 31, no. 40, 3. March 2021. Available

https://www.uvzsr.sk/docs/info/ut/ciastka 40 2021.pdf (In Slovak)

PHA SR, 2021d. Decree of PHA SR, No. 111, 2021 Decree of the Public Health Authority of the Slovak Republic, which imposes measures in the event of a threat to public health on the obligation to cover the upper respiratory tract. Journal of the Government of the Slovak Republic, vol. 31, no. 46, 11. March 2021. Available at: https://www.uvzsr.sk/docs/info/ut/ciastka_46_2021.pdf (In Slovak)

PHA SR, 2021e. Decree of Regional office of the PHA SR Cadca, No. 45, 2020 Decree of the Regional Office of the Public Health Authority with its seat in Čadca, which regulates measures in the event of a threat to public health for the districts of Čadca and Kysucké Nové Mesto. Journal of the Government of the Slovak Republic, vol. 31, no. 51, 19. March 2021. Available at: https://www.uvzsr.sk/docs/info/ut/ciastka_51_2021.pdf (In Slovak)

PHA SR, 2021f. Decree of the PHA SR, No. 133, 2021. Decree of the Public Health Authority of the Slovak Republic, which prescribes measures in the event of a threat to public health to the obligation to cover the upper respiratory tract. Available https://www.uvzsr.sk/docs/info/ut/ciastka_51_2021.pdf (In Slovak) 
PHA SR, 2021g. Decree of the PHA SR, No. 186, 2021. Decree of the Public Health Authority of the Slovak Republic, which prescribes measures when endangering public health to restrict operations and mass events. Available at: https://www.uvzsr.sk/docs/info/covid19/vyhlaska_186.pdf (In Slovak)

Pressman, P., Satyanarayan, N. A., Roger, C. 2020. COVID19 and Food Safety Risk Management and Future Considerations. Nutrition Today, vol. 55, no. 3, p. 125-128. https://doi.org/10.1097/NT.0000000000000415

Shamim, K., Ahmad S. and Alam, M. A. 2021. COVID-19 health safety practices: Influence on grocery shopping behavior. Journal of Public Affairs, p. 1-11. (In press). https://doi.org/10.1002/pa.2624

Sinisterra-Loaiza, L. I., Vázquez, B. I., Miranda, J. M., Cepeda, A., Cardelle-Cobas, A. 2020. Food habits in the galician population during confinement by COVID-19. Nutricion Hospitalaria, vol. 37, no. 6, p. 1190-1196. https://doi.org/10.20960/nh.03213

Tan, W. J., Zhao, X., Ma, X. J., Wang, W., Niu, P., Xu, W., Gao, G. F., Wu, G. 2020. A novel coronavirus genome identified in a cluster of pneumonia cases-Wuhan, China 2019 2020. China CDC Weekly, vol. 2, p. 61-62.

Tanaka, T., Narazaki, M., Kishimoto, T. 2016. Immunotherapeutic implications of IL-6 blockade for cytokine storm. Immunotherapy, vol. 8, no. 8, p. 959-970. https://doi.org/10.2217/imt-2016-0020

UNI Global Union, 2020. COVID-19 guidelines for supermarket workers. Available at: https://www.uniglobalunion.org/news/COVID-19-guidelinessupermarket-workers

UNICEF, 2020. Cleaning and hygiene tips to help keep the COVID-19 virus out of your home. United Nations Convention on the Rights of the Child Available at: https://www.unicef.org/

URL 1, 2020. Lessons From Slovakia-Where Leaders Wear Masks. The Atlantic. 13 May, 2020. Available at: https://www.theatlantic.com/international/archive/2020/05/slo vakia-mask-coronavirus-pandemic-success/611545/

URL 2, 2021. COVID-19 pandemic in Slovakia. Wikipedia. https://en.wikipedia.org/wiki/COVID-

19 pandemic_in_Slovakia

URL 3, 2021. Measures for employers and employees within the COVID automat (Opatrenia pre zamestnávatel'ov a zamestnancov v rámci COVID automat-u). National Labor Inspectorate of the Slovak Republic. Available at: https:/www.ip.gov.sk/opatrenia-pre-zamestnavatelov-

zamestnancov-v-ramci-covid-automat-u/

URL 4, 2021. METRO takes measures to protect employees and customers from COVID-19 (METRO prijíma opatrenia na ochranu zamestnancov a zákazníkov pred COVID-19). Available at: https:/www.metro.sk/tlacove-spravy/opatreniana-ochranu-zamestnancov-zakaznikov-covid-19 (In Slovak)

Wang, C., Pan, R., Wan, X., Tan, Y., Xu, L., Ho, C. S., Ho, R. C. 2020a. Immediate psychological responses and associated factors during the initial stage of the 2019 coronavirus disease (COVID-19) epidemic among the general population in China. International Journal of Environmental Research and Public Health, vol. 17, no. 5, p. 1729. https://doi.org/10.3390/ijerph17051729

Wang, Y., Xu, R., Schwartz, M., Ghosh, D., Chen, X. 2020b. COVID-19 and Retail Grocery Management: Insights from a Broad-Based Consumer Survey. IEEE Engineering Management Review, vol. 48, no. 3, p. 202-211. https://doi.org/10.1109/EMR.2020.3011054
WHO, 2021. WHO Coronavirus (COVID-19) Dashboard. Available at: https://covid19.who.int/region/euro/country/sk

WIKIPWDIA, 2021. Operation Joint Responsibility (Operácia Spoločná zodpovednost'). Available at: https://sk.wikipedia.org/wiki/Oper\%C3\%A1cia_Spolo\%C4\% 8Dn\%C3\%A1_zodpovednos\%C5\%A5

Wu F, Zhao S, Yu B, Chen, Y. M., Wang, W., Song, Z. G., Hu, Y., Tao, Z. W., Tian, J. H., Pei, Y. Y., Yuan, M. L., Zhang, Y. L., Dai, F. H., Liu, Y., Wang, Q. M., Zheng, J. J., Xu, L., Holmes, E. C., Zhang, Y. Z. 2020. A new coronavirus associated with human respiratory disease in China. Nature, vol. 579, p. 265-269. https://doi.org/10.1038/s41586-020$\underline{2008-3}$

Zhao, H., Chen, H., Xiaoyin, M., Yang, G., Hu, Y., Xie, K., Yu, Y. 2019. Autophagy activation improves lung injury and inflammation in sepsis. Inflammation, vol. 42, no. 2, p. 426439. https://doi.org/10.1007/s10753-018-00952-5

\section{Funds:}

This publication was supported by the Operational program Integrated Infrastructure within the project: Demand-driven research for the sustainable and innovative food, Drive4SIFood 313011V336, co-financed by the European Regional Development Fund.

\section{Acknowledgments:}

\section{Conflict of Interest:}

The authors declare no conflict of interest.

\section{Ethical Statement:}

This article does not contain any studies that would require an ethical statement.

\section{Contact Address:}

*doc. Ing. Peter Zajác, PhD., The Slovak University of Agriculture in Nitra, Faculty of Biotechnology and Food Sciences, Department of Food Hygiene and Safety, Tr. A. Hlinku 2, 94976 Nitra, Slovakia, Tel.: +421 37641 4371, E-mail: peter.zajac@uniag.sk

ORCID: https://orcid.org/0000-0002-4425-4374

Ing. Jozef Čurlej, PhD., The Slovak University of Agriculture in Nitra, Faculty of Biotechnology and Food Sciences, Department of Food Hygiene and Safety, Tr. A. Hlinku 2, 94976 Nitra, Slovakia, Tel.: +421 37641 5825, E-mail: jozef.curlej@uniag.sk

ORCID: https://orcid.org/0000-0003-0039-5332

Ing. Lucia Benešová, The Slovak University of Agriculture in Nitra, Faculty of Biotechnology and Food Sciences, Department of Food Hygiene and Safety, Tr. A. Hlinku 2, 94976 Nitra, Slovakia, Tel.: +421 37641 4608, E-mail: xbenesova@uniag.sk

ORCID: https://orcid.org/0000-0002-2321-6627

Ing. Jozef Čapla, PhD., The Slovak University of Agriculture in Nitra, Faculty of Biotechnology and Food Sciences, Department of Food Hygiene and Safety, Tr. A. Hlinku 2, 94976 Nitra, Slovakia, Tel.: +421 37641 4371, E-mail: jozef.capla@uniag.sk

ORCID: https://orcid.org/0000-0001-9475-6359

Corresponding author: * 